ISSN: 0213-2079 - ISSN electrónico: 2386-3889

DOI: https://doi.org/10.14201/shhmo2019411117152

\title{
HACIA EL CAMBIO DE HEGEMONÍA. LA MONARQUÍA HISPÁNICA Y EL IMPERIO ENTRE NÖRDLINGEN Y CORBIE. 1634-1636 ${ }^{1}$
}

\section{Towards a change of hegemony in Europe. The Hispanic Monarchy and the Empire between Nördlingen and Corbie. 1634-1636}

\author{
Fernando NEGREDO DEL CERRO \\ Universidad Carlos III (Madrid) \\ Correo-e: fnegredo@hum.uc3m.es
}

RESUMEN: Las relaciones hispano-imperiales atravesaron diferentes etapas a lo largo de la Guerra de los Treinta Años. En el presente artículo analizamos un periodo muy concreto de las mismas (1634-1636) porque creemos que fue en estos años cuando se gestó el fracaso de una política común que tendrá su último episodio en la paz de Westfalia. Al estudiar en profundidad los tratados negociados en estas fechas buscamos la explicación de por qué, a diferencia de lo ocurrido con Francia y sus aliados, la Casa de Austria fue incapaz de implementar un política común con objetivos militares conjuntos, lo que devino en la pérdida de la hegemonía.

Palabras clave: Felipe IV; Fernando II; Imperio; Conde de Oñate.

ABSTRACT: The relationships between Spain and the Habsburg Empire went through different stages throughout the Thirty Years' War. This article is focused on a very specific period of the war (1634-1636);

1. Este trabajo se inscribe en el proyecto Del manuscrito a las pantallas: Memoria, artefactos y prácticas culturales (del siglo XV a nuestros días) financiado por el MEIyC. Ref. HAR2016-76550P.

Ediciones Universidad de Salamanca / 요 Stud. his., H. ${ }^{a}$ mod., 41, n. 1 (2019), pp. 117-152 
it was at that moment when the failure of a common policy that had its last episode in the peace of Westphalia happened. Studying in depth the treaties negotiated at this time we try to understand why, unlike what happened with France and its allies, the Habsburgs were unable to implement a common military policy that would have prevented their loss of hegemony in Europe.

Keywords: Philip IV of Spain; Ferdinand II; Habsburg Empire; Count of Oñate.

\section{INTRODUCCIÓN ${ }^{2}$}

En fecha tan temprana como 1616, es decir, antes de que se produjeran los acontecimientos que desencadenaron el conflicto que conocemos como Guerra de los Treinta Años, don Baltasar de Zúñiga, a la sazón embajador de su majestad católica ante el emperador, escribía al secretario Juan de Ciriza dándole cuenta de los asuntos de Alemania ${ }^{3}$ y de cómo debía actuar su sucesor, el conde de Oñate. En este interesante informe, además de remarcar el importante papel de la legación diplomática como sostén de los católicos en aquellos territorios, analizar las posibilidades hispanas de acercamiento a los diferentes grupos confesionales - diferenciando claramente a los luteranos de los calvinistas - y explicar la compleja estructura del Sacro Imperio, don Baltasar recordaba, en su parte final, la piedra angular sobre la que descansaba toda la diplomacia:

«Sobre todo es menester dinero y que haya allá cuidado con proveerle a tiempo y acá en distribuirle, en que he hecho lo que he alcanzado, pero el conde, entiendo, que lo hará mejor» ${ }^{4}$.

2. Abreviaturas de centros de investigación empleadas: AGS: Archivo General de Simancas; AHN: Archivo Histórico Nacional (Madrid); BCLM, CL: Biblioteca de Castilla La Mancha (Toledo), Colección Lorenzana; BL: British Library (Londres); BN: Biblioteca Nacional (Madrid); BRBML, PH: Beinecke Rare Books and Manuscripts Library (Connecticut), colección Diplomatic Papers of Graf von Harrach; HHStA: Haus-,Hof-und Staatsarchiv (Viena).

3. Utilizamos el término «Alemania» según se usaba en la época, es decir, para referirse al espacio centroeuropeo, en su mayoría perteneciente al Sacro Romano Imperio, lo que engloba a territorios no alemanes hoy en día como Austria, Bohemia, Moravia, Alsacia, etc.

4. BRBML, PH, vol. 6.2. f. 79. [Agradezco muy sinceramente a Rocío Martínez López que me proporcionara copia de los manuscritos de esta biblioteca]

Ediciones Universidad de Salamanca / @®@@ Stud. his., H. ${ }^{a}$ mod., 41, n. 1 (2019), pp. 117-152 
Teniendo en cuenta la experiencia diplomática de Zúñiga y su profundo conocimiento de la realidad de la Monarquía de Felipe III $^{5}$ estos consejos no pueden considerarse, en ningún caso, superfluos y anticipan con meridiana claridad la cuestión clave en las relaciones entre Madrid y Viena/Praga en los años venideros que girará en torna a la capacidad de la Monarquía Católica para financiar fidelidades y apoyos en el espacio alemán 6 . Más allá de los intereses dinásticos, la defensa de la religión católica o las opciones geoestratégicas, la solidez de la cooperación entre las dos ramas de la casa de Austria se cimentó, casi en exclusiva, sobre la plata que los Habsburgo madrileños fuesen capaces de transferir a los territorios germánicos. Por supuesto los ideales descritos guiaron la toma de decisiones pero su aplicación práctica pivotó sobre algo tan prosaico como el dinero ${ }^{7}$.

$\mathrm{Y}$ en este sentido, nuestra tesis, que intentaremos desarrollar en las siguientes páginas, se centra en describir cómo, más allá de desavenencias personales y cuestiones coyunturales - que de ambas hubo-, el fracaso del proyecto austracista en el contexto internacional de mediados del siglo XVII se debió a un problema estructural que anclaba sus raíces en la diferencia, casi insalvable, de concepción del porqué se luchaba entre los integrantes del pretendido mismo bando. A partir de ahí, como es obvio, y ante la inexistencia de objetivos comunes, todo el edificio diplomático se tambaleaba y por ello era en exclusiva el poder del dinero quien conseguía mantenerlo en pie.

Ahora bien, este fracaso no fue repentino, sino que se verificó con el paso del tiempo y tuvo su punto de inflexión, desde nuestro punto de vista, en los nunca desarrollados tratados hispano-imperiales de los años 1634 y 1635. Su frustración marcará la línea de desencuentro entre las dos ramas de tal manera que, una vez sancionada la inoperancia de tales acuerdos a finales de la campaña de 1636, jamás

5. Para este personaje y su labor político-diplomática, GONZÁLEZ CUERVA, R.: Baltasar de Zuñiga. Una encrucijada de la Monarquía Hispana (1561-1622). Madrid, 2012.

6. Para la evolución posterior de esta cuestión resulta de interés, RODRÍGUEZ HERNÁNDEZ, A.J.: «El precio de la Fidelidad Dinástica: Colaboración económica y militar entre la Monarquía Hispánica y el Imperio durante el reinado de Carlos II, 1665-1700» Studia Historica, 33, 2011, pp. 141-176.

7. El mejor conocedor de la situación, el conde-duque de Olivares, lo exponía de forma meridiana al consultar al rey en respuesta a los despachos llegados de Alemania: «Señor, los negocios que piden prisa a mi juicio son los que votaré aquí sin esperar los puntos del Consejo. $\mathrm{Y}$ en primer lugar diré que todo se reduce a dinero y a muchos dineros; y es menester escribir a Sicilia cómo todo lo de Alemania (que es el todo enteramente del remedio o pérdida de nuestras cosas) consiste en las asistencias de aquel reino.» Voto del conde-duque para el Consejo de Estado [en adelante CE] de 20 de febrero de 1637. AGS, E, leg. 2416.

Ediciones Universidad de Salamanca / అ@@ Stud. his., H. ${ }^{a}$ mod., 41, n. 1 (2019), pp. 117-152 
se llegará a capitular por ambos bandos como hasta ese momento ${ }^{8}$. Son, si se quiere, el fin de una pretendida colaboración militar que había demostrado su fuerza en los campos de Nördlingen pero que, a despecho de buenas intenciones y retóricas altisonantes, no pudo concretarse ninguna vez más. Desde esta perspectiva, la incapacidad por ambos bandos para cumplir los convenios signados se nos aparece como una de las principales razones - a las que habría que sumar otras como la endémica escasez de los recursos empleados en la guerra ${ }^{9}$ - que explican la derrota militar de los Habsburgo y, por tanto, la trasferencia de hegemonía hacia otros contendientes que, por el contrario, sí fueron capaces de llevar adelante, no sin dificultades, sus compromisos bélicos.

A diferencia de los pactos franco-neerlandeses o franco-suecos, discutidos, negociados, criticados..., pero siempre plasmados en actos contundentes ${ }^{10}$, los acuerdos auspiciados por Felipe IV nunca consiguieron involucrar en un plan conjunto y efectivo al resto de signatarios y sólo la inquietud y desasosiego emanado de los avances enemigos forzaron su colaboración. Podemos considerarlos, por tanto, como tratados frustrados sin apenas repercusión práctica en los diferentes escenarios militares, pero en absoluto intranscendentes desde el punto de vista político pues su inviabilidad fue el catalizador de una desconfianza mutua que lastrará toda la relación diplomática entre Madrid y Viena en los años siguientes. De ahí que descendamos a analizarlos con detenimiento fijándonos en el contexto y la letra, así como en sus consecuencias. Con este ejercicio pretendemos poner sobre la mesa las dinámicas de negociación, pero también las limitaciones de la cooperación entre los Habsburgo en un momento crucial de la Guerra de los Treinta Años como fueron los meses previos e inmediatamente posteriores a que la Francia de Luis XIII y Richelieu decidiera dejar su papel secundario y se arrogara el de protagonista principal en la tragedia que sacudía a Europa.

8. El tratado de Ebersdorf de 18 de septiembre de 1639 no puede compararse a los que aquí vamos a tratar pues lo signaba Fernando III como tutor de los hijos del archiduque Leopoldo, junto a la viuda de éste, la archiduquesa Claudia del Tirol. No era, por tanto, un tratado hispanoimperial propiamente dicho. De todas formas, su vigencia fue igualmente casi nula.

9. Véase a este respecto, RODRÍGUEZ HERNÁNDEZ, A.J.:, «Financial and Military cooperation between the Spanish Crown and the Emperor in the Seventeenth Century», en RAUSCHER, P. (Hg.): Kriegführung und Staatsfinanzen. Die Habsburgermonarchie und das Heilige Römische Reich vom Dreissigjährigen Krieg bis zum Ende des habsburgischen Kaisertums 1740, Münster, 2010, pp. 575-602.

10. Aunque conviene reconocer que, a partir de 1640, los tratados franco-neerlandeses comenzaron a tener una menor efectividad debido, precisamente, a la desconfianza de La Haya respecto a las intenciones de París. 


\section{ALGUNAS DESAVENENCIAS PREVIAS. LAS RELACIONES HISPANO IMPERIALES ANTERIORES A 1634}

En consonancia con lo expuesto, conviene recordar que las disputas entre las dos ramas de la Casa de Austria sobre estrategias y decisiones a tomar son rastreables desde casi los inicios del conflicto si bien se dispararán una vez que Francia entre en guerra (1635). Por ello, merece la pena, siquiera, nombrar alguno de esos momentos porque nos ilustran a la perfección sobre las profundas divergencias que arrastraban los pretendidos aliados y además ayudan a comprender el porqué de algunas de las decisiones tomadas a mediados de la cuarta década. Tan sólo mencionaremos brevemente dos: las surgidas en torno a la concesión del electorado a Baviera en 1622-23 y las resultantes de las decisiones tomadas en Alemania entre 1629 y 1631.

Con relación al primer caso, y a pesar de lo que la propaganda calvinista difundió y gran parte de la historiografía anglo-nórdica ha venido manteniendo, Madrid nunca apoyó la transferencia del electorado palatino al duque bávaro. Esto es hoy de sobra conocido, pero no aparece reflejado, todavía, como debiera ${ }^{11}$. Tanto el papel del embajador Oñate como la misma correspondencia real así lo atestiguan. Otra cosa es que, ante los hechos consumados presentados por Fernando II, su sobrino no tuviera más opción que aceptarlo. Y esta evolución se rastrea con sólo leer la correspondencia entre ambos. Así, el 24 de noviembre de 1622, Felipe IV escribía al emperador rogándole que «para el asiento de las cosas de Alemania» era fundamental que no se produjera el traslado electoral por lo menos hasta no haberse convocado una reunión de electores «por las turbaciones que esto podría causar que serían perores que las pasadas». Y a renglón seguido le comunicaba:

«que si con ocasión de la traslación (lo que Dios no permita) sucediesen nuevas alteraciones en Alemania, como es muy verosímil y que serían peores que las pasadas, sentiré mucho el no poder asistir a V.M. porque, demás de las guerras de Flandes, tengo pendientes otras por mar y tierra a que es forzoso no faltar con todas mis fuerzas» ${ }^{12}$.

Sin embargo, las veladas amenazas del rey católico no podían surtir ningún efecto porque la decisión de convertir al duque bávaro en nuevo elector -lo que no era tan sólo una cuestión religiosa, sino que vulneraba todas las constituciones del Sacro Imperio - habían sido tomadas en 1619 mediante un pacto secreto que sólo ahora veía la luz ${ }^{13}$. Por eso, y ante una decisión irrevocable, al cuarto de los

11. NEGREDO DEL CERRO, F.: La Guerra de los Treinta Años. Una visión desde la Monarquía Hispánica. Madrid, 2016, pp. 91-92.

12. BRBML, PH, vol. 2, pp. 1-2.

13. Sobre el elector bávaro puede consultarse KRAUS, A.: Maximilian I. Bayerns Grosser Kurfürst. Graz, 1990, si bien, la visión que da del personaje y su política es, ciertamente,

Ediciones Universidad de Salamanca / అ@@ Stud. his., H. ${ }^{a}$ mod., 41, n. 1 (2019), pp. 117-152 
Felipes sólo le quedo aceptarla pero, con todo, en su acuse de recibo de la ingrata noticia deslizaba su desacuerdo sin que esto fuese óbice para remitir ese mismo día una misiva de felicitación a Maximiliano por su recién adquirida posición ${ }^{14}$.

Si traemos a colación este cruce de cartas es para constatar que desde los inicios mismos del conflicto existió entre los aliados católicos toda una pléyade de espinosos asuntos que no supieron (o quisieron) encauzarse. Porque de los acontecimientos de 1622-1623 quedó un resquemor patente en todas las partes. El flamante elector tenía muy claro que Madrid no había auspiciado su candidatura (algo que la diplomacia papal se encargó de dejarle claro) y nunca perdonaría al conde de Oñate el desaire que había supuesto que no acudiera a su investidura. Olivares, y con él, el Consejo de Estado - una vez fallecido don Baltasar de Zúñiga que había intentado hasta su último aliento impedir la traslación ${ }^{15}-$, interiorizaron que los intereses egoístas de Baviera prevalecerían en cualquier caso frente a las necesidades dinásticas de los Habsburgo ${ }^{16}$ y que la diplomacia papal estaba dispuesta a utilizar de forma espuria el factor religioso para debilitar la posición española en Centroeuropa con las potencialidades que esto ofrecía por la inequívoca fidelidad a Roma que Fernando

condescendiente. Un resumen de las negociaciones para la transferencia destacando el papel de la diplomacia papal en MAREK, P.: «La diplomacia española y la papal en la corte imperial de Fernando II», Studia Historica, 30, 2008, pp. 109-143, pp. 118-120.

14. El rey escribía al emperador el 29 de junio de 1623: «Señor. El conde Khevenhüller me dio la carta de V.M. de 5 de marzo [la transferencia electoral se había consumado el 25 de febrero] y una relación muy particular en que se dicen las causas y motivos que había tenido V.M. para transferir la dignidad electoral palatina en la persona del duque de Baviera y estoy cierto que la intención de que V.M. ha llevado en esto ha sido la misma que en su carta me significa pero como deseo tanto la quietud de Alemania y la seguridad del Imperio en V.M. me recato de que por estos medios se puedan conseguir tales fines, que ha sido lo que me ha obligado a hacerle representación de ello, deseando siempre, como ahora, el acrecentamiento de la persona y casa del dicho duque de Baviera por todas razones que es cuanto se ofrece que decir a V.M., remitiéndome en lo demás a lo que entenderá del dicho conde...» BRBML, PH, vol. 2, p. 37. La carta para Baviera es de esa misma fecha y se puede leer en la p. 41.

15. GONZÁLEZ CUERVA, Baltasar de Zúniga..., afirma que «la cuestión de la traslación electoral fue uno de los puntos cruciales en el desarrollo de la Guerra de los Treinta Años y, posiblemente, el mayor fracaso diplomático de Baltasar de Zúñiga. Este se opuso vivamente a la pretensión de Baviera, pese a ser una potencia amiga, porque para él antecedía la quietud del Imperio y era consciente de que esta innovación introducía un desequilibrio de poder que los protestantes nunca perdonarían», p. 512. Este autor resume con solvencia la posición hispana respecto a dicha cuestión. Cfr, pp. 511-521.

16. Esta idea la ha rescatado STRAUB, E.: Pax et Imperium. Spaniens Kampf um seine Friedensordnung in Europa zwischen 1617-1635. Paderborn, 1980, cuando afirma que el elector bávaro desempeñó un papel funesto para la política alemana pues era un príncipe que sólo perseguía sus propios objetivos «sin que le importaran, ni el Imperio, ni el emperador ni la paz en Europa», pp. 474-475. 
II había venido demostrando desde su juventud ${ }^{17}$. En este sentido, el emperador, ante el dilema que se le había planteado entre la lealtad dinástica o la fidelidad religiosa se decantó por esta última lo que debilitaba los planteamientos hispanos por mucho que la identidad confesional - y sus propagandistas - intentaran ocultarlo.

Tal así, un hecho como el descrito anunciaba ya la enorme distancia que separaba las legitimaciones de actuación con su praxis, convirtiendo la estrategia de los Habsburgo madrileños, a ojos de amigos y enemigos, en una mera defensa de los propios intereses. Ni Olivares, ni Oñate, ni la pléyade de agentes que se sucedieron en la corte cesárea en los siguientes años, supieron hacer ver a sus primos vieneses que lo que se dirimía en el Imperio no era una cuestión confesional, por más que ésta lo impregnara todo intoxicándolo con su carga de irracionalidad, sino un asunto de política interna del Reich y geoestrategia a nivel europeo ${ }^{18}$. Y ante ello era imprescindible, como se clamaba desde España, que ambas ramas hablasen por una sola boca ${ }^{19}$. Si esto no era así y otros condicionantes desviaban al káiser de este norte de actuación, la derrota del planteamiento hispano, y por ende del de la Casa de Austria, en los términos en que ésta se había desenvuelto en el último siglo, estaba asegurado.

Ahora bien, su derrota, bien gestionada, ofrecía enormes posibilidades a amigos y enemigos; aunque dicha gestión se antojaba muy compleja pues podía devenir en catástrofe si ciertos equilibrios se rompían, como demostraron los acontecimientos de 1629-31.

En esta ocasión, de nuevo la voluntad imperial de imponer la versión más intransigente del catolicismo chocó con las recomendaciones hispanas de moderación y prelacía de intereses que, por voz de Olivares, se escucharon en el Alcázar:

$\mathrm{Y}$ es bien que el emperador entienda que, aunque el recobrar los bienes que han ocupado los herejes es cosa tan santa y tan pía, no faltan opiniones de que es mucho

17. Una visión renovadora de la diplomacia papal en tiempos de Urbano VIII la ofrece GIORDANO, S. en trabajos como «Urbano VIII e la Casa d'Austria durante la Guerra dei Trent'anni. La missione di tre nunzi straordinari nel 1632», en MARTÍ́NEZ MILLÁN, J. y GONZÁLEZ CUERVA, R.: La Dinastía de los Austria. Las relaciones entre la Monarquía Católica y el Imperio. Madrid, 2011, pp. 227-247.

18. La cuestión confesional de la guerra de los Treinta Años es un tema, aun hoy en día, muy debatido. Nuestra opinión al respecto puede leerse en NEGREDO DEL CERRO, F.: «¿Una guerra de religión o una religión para la guerra? El elemento confesional en la Guerra de los Treinta Años», Hipogrifo. Revista de literatura y cultura del Siglo de Oro, 7.2, 2019 [en prensa].

19. «Conviene abrir los ojos y hacer que los abran el emperador y el rey de Hungría procurando a cualquier precio o por los ministros o por los príncipes, ganar precisamente la inseparable unión sin que se hable por dos bocas...» Voto del conde-duque para el CE de 27 de noviembre de 1635, AGS, E, leg. 2336. 
mayor beneficio para la religión católica el procurar reducir los príncipes y los estados del Imperio aunque fuese absolviéndoles y donándoles los bienes eclesiásticos que poseen. Pues el quitárselos lo atribuyen a avaricia de los eclesiásticos y no a caridad y el dejárselos podría ser causa de que algunos príncipes se convirtiesen y con cada uno que lo hiciere se convierta su estado. Y si el emperador llegarse a persuadirse a suspender el edicto de restitución de estos bienes y a tentar es otro camino, sería el conde de opinión que el embajador de V.M. procure venderlo al ministro del elector de Sajonia que reside en aquella corte dándole en cualquier evento y en todas ocasiones a entender que, como el mismo elector sabe, V.M. siempre ha deseado la paz y quietud en el Imperio y en este caso diera lo mismo ${ }^{20}$.

Desoyendo estos consejos que desde Madrid se hicieron llegar a Viena, Fernando II decidió implementar el Edicto de Restitución, soliviantando todos los ánimos y colocándose en una posición de debilidad que quedó puesta de manifiesto en las negociaciones de Ratisbona ${ }^{21}$ : la claudicación frente a los electores católicos que supuso el apartamiento de Wallenstein, unida a la humillación de no conseguir la condición de rey de romanos para su hijo, dejaron al emperador (mucho más receptivo a las palabras de su confesor, el jesuita luxemburgués, Lamormaini, que a la de los enviados de Felipe IV $^{22}$ ) en una situación de manifiesta inferioridad político-militar, justo cuando Francia había decidido involucrarse con determinación en el valle de $\operatorname{Rin}^{23}$. Para entonces, las negociaciones que en secreto se habían mantenido entre emisarios españoles y el duque de Friedland, la gestión del socorro de Mantua y las desavenencias en torno al viaje de la reina de Hungría, la infanta María, habían conseguido, en palabras del secretario de la embajada Pedro de Villanueva, inocular en «los ánimos del emperador y sus ministros una tan tenaz pertinacia en creer que se ha procedido con ellos con simulación y segunda intención». Esta desconfianza demandaba, según este diplomático, un cambio radical de actitud que, se suponía, sólo podría darse con un giro en la posición española ${ }^{24}$. La naturaleza de este viraje se la explicitaba don Gaspar de Guzmán al rey en un voto particular al recordarle:

20. Voto del conde-duque para el CE de 24 de diciembre de 1630, AGS, E, leg. 2331.

21. RÓDENAS VILAR, R.: La política europea de España durante la Guerra de Treinta Años (1624-1630). Madrid, 1967, pp. 266-275.

22. Para esta temática y la bibliografía relacionada, NEGREDO DEL CERRO, F. y VILLALBA PÉREZ, E.: «Los jesuitas y la Monarquía Hispánica en el contexto de la Guerra de los Treinta Años (1625-1635)», Hispania Sacra, LXVII, 136, 2015, pp. 635-672. El contexto de la mal llamada dieta de Ratisbona de 1630 - en realidad, «convento electoral»-, en WILSON, P. H.: Europe's Tragedy. A history of the Thirty Years War. Londres, 2009, pp. 454-458.

23. WEBER, H.: «Richelieu et le Rhin», Revue Historique, 239, 2, 1968, pp. 265-280.

24. Carta del secretario Pedro de Villanueva para Olivares, Viena, 16 de julio de 1631. AHN, E, lib. 712. 
«Demás de esta causa general para la poca afección con nosotros, se junta el disgusto particular de algunos de los electores y otros príncipes por no pagárseles las pensiones y hacérseles efectivas otras mercedes del rey N.S. [...] En conclusión de este papel que para granjear y alcanzar del emperador y del Imperio así la gente como todo lo demás que de ellos se quiera es la mayor lección y más cierta (asegurándoles de las sospechas que tienen de nuestras intenciones) tener proveída aquella embajada porque los alemanes son naturalmente amigos del dinero, y como le haya, hacen lo que se quiere de ellos...» ${ }^{25}$.

Era, por tanto, dinero, mucho dinero lo que se necesitaba para reconducir las negociaciones en el espacio germánico. Eso, y una mayor presión sobre el emperador para que prestara más atención a sus escasos consejeros pro-españoles, en especial a Eggenberg, desoyendo los cantos de sirena de otros muchos ministros ganados, a ojos del Consejo de Estado, por el oro francés ${ }^{26}$. Pero lo uno escaseaba ${ }^{27}$ y lo otro, con una embajada descabezada tras el traslado del marqués de Aytona a Flandes, era muy difícil de conseguir ${ }^{28}$. Con todo, la vertiginosa evolución de los acontecimientos bélicos actuó en beneficio de los intereses hispano en la línea de lo ya mencionado: sólo el miedo a los enemigos actuaba de aglutinante entre los pretendidos aliados. Y en 1631 el gran enemigo se llamaba Gustavo Adolfo.

La irrupción sueca, que fue mucho más allá de lo inicialmente previsto por unos y otros, desmanteló la estrategia bávara que había iniciado un claro viraje tras

25. Ibidem. Una «Memoria de todos los pensionarios que hay vivos, lo que tienen cada año y lo que se les debe hasta fin de junio de 1629» realizada por el conde de Oñate y enviada a Madrid el 29 de agosto, recordaba todas las deudas tanto a ministros imperiales como a príncipes del Imperio destacando, por ejemplo, los más de 70.000 ducados que se debían al elector de Colonia. AGS, E, leg. 2510. Estos datos pueden compararse con la «Relación de las pensiones y entretenimientos que se pagan en la embajada de Alemania demás de los sueldos de Embajador residente y Secretarios», BL, Add. 14004, f. 476.

26. Olivares, en el CE de 8 de junio de 1631, se refería a este tema con las siguientes palabras: «Lo peor es que la voluntad del emperador está muy bien dispuesta y con gran afición a todas las cosas de V.M. sino que está sitiado de traidores por todas partes y aunque los llegue a conocer, su natural piedad le arrastra contra sí a excusar el castigo y escarmiento». AGS, E, leg. 2332.

27. Es muy ilustrativo a este respecto el real decreto de 15 de junio de 1631 en el que, entre otras cosas el rey ordenaba remitir 312.000 escudos a Alemania y advertir a su embajador en el Imperio «que no se ha de gastar más de lo que tengo mandado por lo que conviene ir reservando este dinero y no gastarle si no es a negocio hecho porque la experiencia ha mostrado cuan perdido fue lo que se gastó en Ratisbona por otro camino [...] y que se asegure que he tenido por milagro el haberse podido negociar este dinero en el estado en que está todo». AGS, E, leg. 2332.

28. Las órdenes y contraórdenes sobre el personal de esta embajada se pueden seguir en NEGREDO DEL CERRO, F.: «Un episodio español en la Guerra de los Treinta Años: La embajada del marqués de Cadreita al Sacro Imperio y el acercamiento al Elector Sajón (16291631)», Hispania, vol. LXXV, 251, 2015, pp. 669-694, pp. 673-674.

Ediciones Universidad de Salamanca / @®@@ Stud. his., H. ${ }^{a}$ mod., 41, n. 1 (2019), pp. 117-152 
el tratado de Fontainebleau, y obligó a Maguncia y Tréveris a resituarse, uno, de nuevo en la órbita hispana ${ }^{29}$, otro, acogiéndose a la protección gala ${ }^{30}$.

Pero esta crisis - que puede y debe analizarse con más detenimiento desde la óptica hispana ${ }^{31}$ - volvió a poner de manifiesto el axioma general que presidía las complejas relaciones entre la Monarquía Hispánica y los diferentes príncipes alemanes: sus divergencias en cuanto a objetivos de guerra y sus concomitancias en relación a unos enemigos que, envalentonados en la victoria, impedían unos acuerdos de paz equilibrados. Mientras Gustavo Adolfo aterrorizó a los católicos y desmanteló todos los compromisos previos, los electores eclesiásticos, Baviera y el Imperio caminaron juntos rogando, cuando no exigiendo, al rey hispano que los protegiera ${ }^{32}$. Pero una vez difuminada su amenaza por la muerte del soberano escandinavo y, sobre todo, tras la derrota de Nördlingen, de nuevo las discrepancias entre todos ellos salieron a la luz. Y Francia, cuya diplomacia contaba con la ventaja añadida de una liquidez amplia y fija, jugó sabiamente la carta de ahondarlas desbaratando de forma definitiva la estrategia Habsburgo para el espacio germánico. Si bien, en honor a la verdad, el proceso fue largo y complejo. Del inicio del mismo damos cuenta a continuación.

29. Para la actuación de Anselm Casimir Wanbold, elector de Maguncia, BOURDEU, E.: Les archevêques de Mayence et la présence espagnole dans le Saint-Empire (XVIe-XVIIe siècle). Madrid, 2015, pp. 196-220.

30. El elector de Tréveris, pretextando «que el emperador ha retirado sus tropas y, asimismo, que el rey de España no tiene bastante poder para defenderse contra las fuerzas de tantas potencias unidas, cuanto más para ayudar a otros...» decidió ponerse bajo la protección de Luis XIII en diciembre de 1631, algo que su propio cabildo no aceptó, procediendo a invocar la intervención de Felipe IV «sin disputa, protector de esta ciudad» lo que le forzó al arzobispo a firmar con el rey galo un tratado de defensa el 9 de abril de 1632 y la intervención directa del ejército francés a principios de agosto de ese año sobre su capital para expulsar a la guarnición española. ABREU Y BERTODANO, J. A. DE.: Colección de los Tratados de Paz de España. Reinado de Felipe IV. Parte II, Madrid, 1745, pp. 326-328 y 366-371. Véase al respecto también lo que escribe Alicia Esteban Estríngana en este mismo dossier.

31. Sumándose así a los trabajos clásicos pero parciales de Ródenas, Beladiez, y, sobre todo, ALDEA VAQUERO, Q.: España y Europa en el siglo XVII. Correspondencia de Saavedra Fajardo. Madrid, 4 vols., 1986-2008, en especial vol. I y II.

32. Muestra de ello es el tratado de 14 de febrero de 1632 (vid. nota 37) y las negociaciones bávaras para volver a la gracia imperial citadas en BELADIEZ, E.: España y el Sacro Imperio Romano Germánico. Wallenstein (1583-1634). Madrid, 1967, p. 290. Vid., también, ERNST, H. Madrid und Wien 1632-1637. Politik und Finanzen in den beziehungen zwischen Philipp IV und Ferdinand II. Münster, 1991, pp. 33-44.

Ediciones Universidad de Salamanca / అ@@ Stud. his., H. ${ }^{a}$ mod., 41, n. 1 (2019), pp. 117-152 


\section{DEL EFÍMERO TRATADO DE 1634 A LA FRACASADA CAMPAÑA DE 1636}

Tras la victoria de Nördlingen y la posterior llegada del Cardenal Infante a Flandes, proceso que ocupó el final del verano e inicio del otoño de 1634, la situación geopolítica había dado un vuelco impensable nueve meses antes. Asesinado Wallenstein y eliminada la amenaza sueca sobre el valle del Danubio los actores del drama habían variado sustancialmente. El bando católico podía, ahora, poner en marcha una doble política con el fin de concluir la guerra que ya hacía más de quince años desgarraba Europa: por un lado, aprovechando el reflujo protestante y las tropas que comandaba don Fernando, eliminar al máximo posible la presencia anti-imperial en el valle del Rin y territorios aledaños; por otro, alcanzar un acuerdo de paz con los luteranos que permitiera reconducir la situación aislando a los calvinistas más intransigentes ${ }^{33}$.

Con respecto a la primera opción, el Cardenal Infante consintió en ceder diferentes efectivos al comandante en jefe de la liga católica, Felipe de Mansfeld, para que pudiera cooperar con las fuerzas del rey de Hungría - el futuro emperador Fernando III - y las de su principal general, Matteo Galasso. Éstas se hallaban empeñadas en la limpieza y ocupación del Palatinado y control de los vados del Rin, lo que, además de afectar a los príncipes calvinistas aún insurrectos, debilitaba, sobre todo, la estrategia francesa en la zona. Estrategia diseñada desde principio de los años treinta y que tenía como epicentro el ya citado electorado de Tréveris. Por ello, ante la variación en el equilibrio regional, la respuesta de Richelieu no se hizo esperar ordenando ocupar algunos puestos clave en el curso del río, decisión que, sumada al tratado franco-neerlandés que se negociaba y se verificará en marzo de 1635 (que estipulaba el reparto de las Provincias Obedientes si ignoraban el llamamiento a la sublevación y oponían resistencia a los dos invasores), obligó a la invasión hispana del Electorado arzobispal, con sus conocidas consecuencias ${ }^{34}$.

En relación a la segunda, las negociaciones con Sajonia - siempre bienquistas por la Monarquía $a^{35}$ - se asentaron, demostrando la fragilidad del frente protestante

33. Todos estos aspectos se tratan de forma pormenorizada en los ensayos que introducen la correspondencia entre el conde-duque de Olivares y el Cardenal infante publicada por ELLIOTT, J. H. y NEGREDO DEL CERRO, F. (eds): Memoriales y Cartas del Conde Duque de Olivares, t. II, Política exterior: Correspondencia entre el Cardenal Infante y don Gaspar de Guzmán, Madrid 2018 [en prensa].

34. Sobre este particular, ESTEBAN ESTRÍNGANA, A.: ««Dar ley a los otros»y emanciparse de ella: balance de hegemonía en las dos guerras de Flandes (1635-1646)» en este mismo dossier.

35. Merece la pena rescatar un texto ológrafo de Felipe IV en respuesta a una consulta del CE, 2 de diciembre de 1635, tras la firma de la paz de Praga: «Como parece; y podránse enviar también cartas para Sajonia con [quien] conviene cumplir con esta ocasión de la paz

Ediciones Universidad de Salamanca / అ@@ Stud. his., H. ${ }^{a}$ mod., 41, n. 1 (2019), pp. 117-152 
y obligando a los disidentes, en especial a la Liga de Heilbronn, a situarse indefectiblemente en la órbita francesa ${ }^{36}$. De hecho, antes de haberse cumplido los tres meses de la derrota de Weimar y Horn en Nördlingen, el elector Juan Jorge firmaba los «Preliminares de Pirma» que, aunque combatidos por el ala más radical de la corte imperial, acabarán cuajando en la primavera de 1635 en la Paz de Praga ${ }^{37}$.

En este contexto, la diplomacia imperial decidió enviar un nuevo embajador a Madrid, el conde de Schönburg, para reforzar su posición negociadora. En su viaje, este legado atravesó Francia antes de entrar en la Península entrevistándose en París con Luis XIII y Richelieu, reunión en la que se le aseguró la buena voluntad del rey Cristianísimo hacia la Casa de Austria. Con tal bagaje llegó a la corte española a mediados de octubre, aunque todavía tardaría unos días antes de ser recibido por Felipe IV ${ }^{38}$.

Mientras tanto, los nuevos embajadores hispanos en Viena, el ordinario, don Sancho de Monroy, marqués de Castañeda y el extraordinario, don Íñigo Vélez de Guevara, conde de Oñate ${ }^{39}$, recibieron instrucciones claras para signar un nuevo acuerdo que sustituyese al firmado en 1632 ya que el horizonte tanto militar como político había variado sustancialmente tras los sucesos descritos ${ }^{40}$. Surge así el

pues siempre conviene mantener a aquel elector por amigo». AGS, E, leg. 3337. En realidad esta opinión sobre Sajonia la compartía el rey con sus ministros. De hecho casi por las mismas fechas el conde de Oñate le escribía aconsejándole: «Y al elector de Sajonia se podría, si V.M. fuese servido, en esta misma carta o en otra, aparte darle el parabién de haberse reconciliado con el emperador y vuelto a la sincera amistad que entre estas casas ha habido tantos siglos con la recíproca conveniencia y mucha utilidad del Imperio». El conde de Oñate a Felipe IV, Viena, 30 de enero de 1636. AGS, E, leg. 2337.

36. El 1 de noviembre se firmaría el Tratado de París entre Suecia, Francia y la mencionada Liga por la que ésta pasaba a depender en lo económico y militar de Francia. Las condiciones impuestas por Richelieu no gustaron a Oxenstierna quien se negó a ratificar el tratado continuando una negociación particular que mejorase la posición sueca. WILSON, Europe's Tragedy..., pp. 551-552.

37. BIRELEY R.: «The Peace of Prague (1635) and the Counterreformation in Germany», The Journal of Modern History, vol. 48, 1, 1976, pp. 31-70.

38. El 19 de agosto de 1636, Schönburg informaba de su llegada a París y de «la mala disposición hacia Suecia existente en Francia». Seis días después escribía cómo Luis XIII se encontraba enfermo de podagra y todavía no le había podido recibir, pero el cardenal Richelieu y el padre José querían visitarle. El 21 de septiembre reportaba a su señor la audiencia tenida con el rey Cristianísimo y el 17 de octubre informaba de su llegada a Madrid y de que no había «hasta la fecha hablar con Olivares por dificultades de protocolo». HHStA, Staatenabteilungen. Spanien. Diplomatische Korrespondenz, Karton 23. [Agradezco a Roberto Quirós que me proporcionase las referencias de este archivo].

39. Sobre la embajada de Oñate, decidida a principios de 1633, ELLIOTT, J. H.: El Conde-Duque de Olivares. El político en una época de decadencia. Barcelona, 1990, p. 452.

40. Este tratado se había firmado el 14 de febrero de 1632 en Viena, al calor de las derrotas de Tilly frente a los suecos. Lo habían negociado por parte hispana el marqués de Cadreita y

Ediciones Universidad de Salamanca / అ@@ Stud. his., H. ${ }^{a}$ mod., 41, n. 1 (2019), pp. 117-152 
tratado de Ebersdorf de 31 de octubre de 1634 entre Felipe IV y Fernando II que, si bien es heredero en las formas del de 1632, se aleja notablemente en el fondo. En él se estipulaba que se debería poner en pie un ejército de 30.000 infantes y 10.000 jinetes para que sirviese a los coaligados y a todos aquellos que quisieren adherirse al acuerdo ${ }^{41}$. Un tercio de esta fuerza (o su equivalente en dinero: 65.000 escudos mensuales) sería aportado por Madrid, comprometiéndose el emperador a sostener el resto. Dicho ejército podría operar en el Imperio, siempre a las órdenes del káiser, o fuera de él, estando entonces bajo el mando del rey católico.

Ahora bien, aunque los artículos del tratado público eran de gran importancia para la Monarquía pues abrían la puerta a una posible coalición en la que cabrían otros príncipes sin que el credo fuese un excluyente, lo realmente interesante y novedoso del acuerdo eran sus cláusulas secretas merced a las cuales Fernando II se comprometía:

«a dar asistencia al Serenísimo Rey Católico, como duque de Borgoña y príncipe a quien debe tanto el Imperio; [...] Demás de esto, su Cesárea y real Majestad promete, por sí y por sus herederos y sucesores en los reinos y provincias hereditarias, que ayudará cuanto pueda a su Majestad Católica en la referida guerra así en las provincias de Flandes como en otra cualquiera parte donde se hiciese guerra defensiva o, con el consentimiento de todos, ofensiva; y que el ejército de esta alianza acudirá a las partes y círculos inmediatos al Rin, Mosa y Mosela según que la necesidad del Imperio y de las provincias de su Majestad Católica lo permita y a su Majestad Católica le convenga [...] Y se observará en Flandes con el serenísimo Infante de España la misma correspondencia que si su Majestad estuviese allí personalmente» ${ }^{42}$.

Jacques Bruneau. Su finalidad era hacer frente a «Gustavo Adolfo, rey de Suecia y sus confederados» y, para ello, acordaba la coalición de las fuerzas hispano-imperiales que habrían de llegar a los 64.000 hombres (51.000 de infantería y 13.000 de caballería, aportando Felipe IV, 21.000 y 5.000 efectivos, respectivamente) operativos durante seis años, tanto en el Imperio como, si así lo demandaban las circunstancias, en los territorios del rey católico. La medida había sido consensuada, no sin grandes dificultades, y su puesta en práctica se verificaría muy compleja. El contenido del mismo se puede leer en ABREU Y BERTODANO, Colección de los Tratados de Paz de España..., II, pp. 342-349. Cfr. ERNST, Madrid und Wien 1632-1637..., pp. $42-44$.

41. El acuerdo se llevaba negociando desde primavera como demuestra el borrador de marzo - coincidente en lo sustancial con el texto final - así como otros documentos complementarios que pueden leerse en AGS, E, leg. 2335, 75-78 y reproduce GÜNTER, H.: Die Habsburger-Liga (1625-1635). Berlín, 1908, pp. 408-413. La idea original, muy retocada, partió de Olivares y se plasmó en la carta e instrucciones enviadas a Castañeda el 17 de septiembre y 4 de octubre de 1633. En ellas se le animaba a poner en marcha una «Liga de la paz y restauración de las violencias y atentados y mantenimiento de los aliados» en la que debían entrar, además del papa y los príncipes católicos del Imperio, la reina madre de Francia, el duque de Orleans y el de Lorena. AHN, E, leg. 2865, 7.

42. ABREU Y BERTODANO, Colección de los Tratados de Paz..., II, pp. 606-607. Como se aprecia, en ningún lugar del tratado se menciona de forma explícita a Francia ni

Ediciones Universidad de Salamanca / అ@@ Stud. his., H. ${ }^{a}$ mod., 41, n. 1 (2019), pp. 117-152 
Este tratado de 1634 supone, por tanto, a primera vista, un gran avance en los esfuerzos hispanos por involucrar a la rama vienesa en la guerra flamenca, pretensión que había sido el norte de actuación de la diplomacia filipina durante décadas y para la que tanto dinero se había invertido y ahora parecía comenzaba a dar sus réditos. Sin embargo, no fue así.

A pesar de la solemnidad con que se diligenció el acuerdo, su vigencia fue mínima ya que la captura del elector de Tréveris al inicio de la primavera de 1635 (acción que escandalizó a ciertos sectores católicos y no sólo alemanes) y la posterior declaración de guerra francesa trastocaron todo el plan previsto, anulándolo en la práctica y forzando una nueva negociación ${ }^{43}$.

Y es que, desde mayo de ese año ya no serán las Provincias Unidas sino Francia el principal enemigo a batir, sin que esto implicase dejar de hacer la guerra a La Haya con todas las fuerzas disponibles. Dentro de esta lógica se necesitaba una colaboración más estrecha del emperador en la guerra contra Luis XIII dejando a un lado el acuerdo de Ebersdorf que, como hemos visto, primaba el frente neerlandés. Ahora bien, convencer a Fernando II y demás aliados de este viraje estratégico no iba a ser fácil pues esta idea de involucrar al Imperio en un conflicto antifrancés no era compartida por casi nadie en el Reich. Por eso, la declaración de guerra entre París y Viena se retrasaba sine die a pesar de los ruegos y demandas del rey católico y sus ministros que sospechaban profundas deslealtades entre algunos diplomáticos cesáreos, especialmente el residente imperial en París ${ }^{44}$. Tal situación propició que

mucho menos que Fernando II se comprometiese a declarar la guerra al reino galo por lo que no podemos coincidir con lo expresado en BÉRENGER, J.: «La collaboration militaire austr-espagnole aux XVIe-XVIIe siècles», en MOLINIÉ, A. y MERLE, A. (dirs.): L'Espagne et ses guerres. De la fin de la Reconquête aux guerres d'Indépendance. París, 2004, pp. 11-33, p. 21, ni en este punto ni cuando afirma que Olivares rehusó participar en las conversaciones diplomáticas que el emperador y el rey Cristianísimo decidieron emprender.

43. La captura del elector de Tréveris por parte de unidades del ejército de Flandes procedentes de Luxemburgo se verificó el 26 de marzo. La declaración de guerra francesa, excusada en este hecho, se produjo el 19 de mayo. Para contextualizar este episodio, ofrece nueva luz ESTEBAN ESTRÍNGANA, A.: «Olivares y el Cardenal Infante en el gobierno de Flandes: el desafío franco-holandés a la conservación de la provincias entre 1635-1641», en ELLIOTT y NEGREDO, Memoriales y cartas..., vol. II, y su contribución en este dossier. Vid., también, STRADLING, R. A.: «Olivares and the origins of the Franco-Spanish War, 1627-1635», English Historical Review, 101, 1986, pp. 68-94 y el análisis de PARROTT, D.: «The Causes of the Franco-Spanish War of 1635-59», en BLACK, J. (ed.), The Origins of War in Early Modern Europe. Edimburgo, 1987, pp. 72-111; y LESAFFER, R.: «Defensive, Warfare, Prevention and Hegemony. The Justifications for the Franco-Spanish War of 1635» (Part I and Part II), Journal of the History of International Law, 8, 2006, pp. 91-123 y 141-179.

44. MALETTKE, K.: «France's Imperial Policy during the Thirty Years War and the Peace of Westphalia», en BUSSMANN, K. y SCHILLING, H. (eds): 1648: War and Peace in Europe. Münster, 1998, pp. 177-185, afirma, sin dar referencia, que el enviado imperial

Ediciones Universidad de Salamanca / 요 Stud. his., H. ${ }^{a}$ mod., 41, n. 1 (2019), pp. 117-152 
fuese el propio monarca quien escribiera a su tío reprochándole que, a pesar de los esfuerzos de su corona en ayudar a la rama austriaca ${ }^{45}$ :

«no sé que V.M. haya declarado la guerra a Francia por edicto público, dejándome sólo en la rotura, cuando se está viendo lo que el rey de Francia obra contra V.M. y el Imperio. Y no solamente no se publica de parte de V.M. lo que se ha ofrecido, sino [que] se mantiene un residente de V.M. en París ganado por el cardenal Richelieu y Mazarini y confidente de entre ambos, según me informan, de que se vale el rey de Francia para que sus vasallos mal contentos crean que no está roto con el imperio y no se atrevan a quitar la máscara ${ }^{46}$.

Poniendo de manifiesto que la falta de colaboración por parte de la rama germana de la dinastía exaltaba los ánimos de los consejeros de estado pues debilitaba toda su estrategia para Centroeuropa incluida la posible alianza con los príncipes malcontentos franceses.

El retraso en la decisión de dejar vacante la embajada parisina y la nunca publicación de un edicto o similar declarando la guerra explica el tono de algunas cartas como la siguiente, fechada en Madrid el 24 de enero de 1636:

«También extraña S.M. Católica mucho, que contra lo capitulado y firmado entre S.M. Cesárea y el rey mi señor se dude y llegue a negar el declararse en guerra abierta con Francia, siendo así que, además de esta obligación expresa, la paz de Sajonia no sólo no la contradice sino la aprueba por ser ejecución de la paz de Ratisbona y expresamente en la restitución total de Lorena; que todo junto causa en el rey mi señor poco menos que el último desconsuelo» ${ }^{47}$.

- suponemos que el embajador - se fue de París entre el 17 y 25 de agosto. El mismo autor afirma que Fernando II decidió dejar vacía la embajada imperial de Francia en marzo a la vez que expulsaba al enviado francés en Viena, Charbonnières, p. 183. De ahí se puede inferir que quedase en la capital francesa este residente tan malquisto a los españoles entre agosto del 1635 y marzo de 1636.

45. Las sospechas sobre el legado imperial en París, que el rey menciona en el texto que glosamos a continuación, las había levantado un informe de don Antonio Sarmiento del que se daba cuenta a Oñate el 6 de noviembre notificándole que el residente cesáreo «es persona mal afecta a mi servicio porque habla indecentemente es este particular y muestra que son diferentes los intereses de su amo de los míos. Y con esta puerta, que ha abierto, se ha estrechado Mazarini con él, introduciéndole en Francia con el padre José y con el cardenal Richelieu, entre quienes se habían empezado negociaciones secretas. Será bien, vos procuréis, que ahí sea castigado este residente como merece por lo que puede importar al servicio de S.M.Ces ${ }^{a}$ y al mío» Carta de Felipe IV para el conde de Oñate, AGS, E, leg. 2461.

46. Minuta de carta emanada del CE de 5 de octubre de 1635 y fechada el 9. AGS, E, leg. 2461.

47. Carta del conde-duque para el embajador Schönburg, AGS, E, leg. 2462. El emperador se había escudado en que una declaración de guerra a Francia vulneraría la paz de Praga

Ediciones Universidad de Salamanca / అ@@ Stud. his., H. ${ }^{a}$ mod., 41, n. 1 (2019), pp. 117-152 
Y es que, lo que a ojos de Felipe IV y su valido parecía meridiano, al otro lado del Rin se entendía de manera diferente. Para los jerarcas de la Monarquía Católica, Francia, las Provincias Unidas, Suecia, la mayoría de los príncipes calvinistas y los duques de Saboya, Parma, Mantua y Módena formaban parte de un todo - donde se temía pudiera entrar incluso Constantinopla - que no tenía más objetivo que destruir a la casa de Austria y repartirse sus despojos con el beneplácito del papa Urbano VIII ${ }^{48}$. Y ese plan lo corroboraban los diferentes tratados firmados por Francia en los últimos tiempos ${ }^{49}$.

Por el contrario, una parte sustancial de los príncipes católicos centroeuropeos entendían que el principal conflicto al que debían y tenían que enfrentarse no era otro que la expansión sueca y la intransigencia de los sectores más radicales del calvinismo. No estimaban que los duques italianos fuesen sus rivales ni que las Provincias Unidas pudieran considerarse como verdaderos enemigos ya que habría mucho más que perder que ganar en un enfrentamiento directo con La Haya por lo que convenía seguir manteniendo la neutralidad ${ }^{50}$. Por si fuera poco, el oro y la propaganda francesa habían logrado que se considerase al rey Borbón como el protector del catolicismo y defensor de la neutralidad en el Rin y único capaz de enfrenar a los suecos, cuya amenaza, sobre todo tras la firma del acuerdo de Sztumska Wies (12 de septiembre de 1635) entre Suecia y Polonia ${ }^{51}$, multitud de ministros imperiales sentían más próxima al ser grandes señores de feudos bohemios, silesios y moravos.

firmada con Sajonia en mayo. Tal interpretación interesada no tenía, como se aprecia, ningún viso de credibilidad en Madrid.

48. Los embajadores españoles en Viena, siguiendo órdenes de Madrid cursadas en otoño, solicitaron en Viena a principios de 1636: $1^{\circ}$ Que el emperador, a través de los residentes ante la Sublime Puerta trabajara en contra de las gestiones francesas. $2^{\circ}$ Que se declarase la guerra a Francia retirando a los residentes imperiales de ella. $3^{\circ}$ Que se ayudase a remediar los excesos del duque de Saboya en algunos feudos imperiales en Italia. HHStA, Staatenabteilungen. Spanien. Diplomatische Korrespondenz, Karton 23.

49. En la corte española se tenía perfecta constancia de las negociaciones entre todos los agentes citados y que acabaron dando lugar, entre otros, al tratado de Rívoli (donde se sancionaba el reparto de Milán) o el ya citado tratado franco neerlandés que dividía los Países Bajos leales entre estas dos potencias. Ambos se verificaron en el primer semestre de 1635. Para ponderar su contenido, en absoluto defensivo, ABREU Y BERTODANO, Colección de los Tratados..., III, pp. 1-34 y pp. 94-103. De la misma forma las negociaciones entre París y Estocolmo eran continuas, aunque el acuerdo explícito, tratado de Wismar, no se firmaría hasta el año siguiente. Para el contexto general, NEGREDO, La Guerra de los Treinta Años..., pp. 195-206.

50. Sobre la neutralidad de los diferentes príncipes germánicos en el conflicto hispanoneerlandés tiene una muy interesante reflexión Diego Saavedra Fajardo en un texto no publicado que se contextualiza en el entorno de la Dieta de Ratisbona de 1640. Cfr. MONOSTORI, T.: "Antineutralidad: An unknown and unpublished book of Diego de Saavedra Fajardo», Janus, 7, 2018, pp. 1-18. Nosotros hemos utilizado de esta obra, el ejemplar de BN. Mss. 432, ff. 1-73v.

51. Acuerdo auspiciado por la diplomacia franco-británica y la holandesa. ROBERTS, M.: From Oxenstierna to Charles XII: Four Studies. Cambridge, 2003, pp. 45-46. SKOWRON,

Ediciones Universidad de Salamanca / అ@@ Stud. his., H. ${ }^{a}$ mod., 41, n. 1 (2019), pp. 117-152 
Así pues, ante un análisis tan dispar de una misma realidad no resulta extraño que el tratado alcanzado a finales de 1635 , y que venía a sustituir al ya citado de octubre del año anterior, resultara tan poco efectivo por la lectura e interpretación tan diferente que del mismo se hizo.

Contextualizado por las enormes dificultades con las que tuvo que enfrentarse la Monarquía en el primer año de guerra tota ${ }^{52}$, el acuerdo fue producto del apremio con que Madrid ordenó a sus representantes en el Imperio, especialmente a Castañeda - quien se encontraba acompañando al rey de Hungría-, que negociasen. En este sentido, en octubre de 1635 (nótese, justo un año después de la firma en Ebersdorf) se le escribía que ante la inactividad de las fuerzas imperiales frente a Francia intentara reunir fuertes contingentes que pudiesen acudir a Milán y también, «si fuere posible» a Frisia para apoyar la posición del Infante entorno a Güeldres y Schenkenschans (el Esquenque español) punto clave a defender en la próxima campaña. Sin embargo, al final de la misiva se le sugería:

«Pero, si a cualquier precio o capitulación por difícil y costosa que sea, pudiéredes conseguir que invernen en la forma que se ha dicho antes, podréis esto a todo que, en la misma manera que vos lo capitiulárades, se ratificará acá. E iréis dando cuenta de todo al conde de Oñate porque negocie con el emperador, mi tío. Y a mí me la daréis también, por todos los caminos que os sean posibles, de lo que se fuere disponiendo y ejecutando en esto. Y el tiempo está tan adelante, que conviene ganar las horas en ello».53

Y es que la colaboración imperial era cada día que pasaba más necesaria, ya que Olivares deseaba realizar en la próxima campaña una jugada maestra para lo que era imprescindible la cooperación, sin excusas, de sus aliados germanos.

Lo que don Gaspar se encontraba diseñando con frenética actividad desde finales del otoño de 1635 era una posible tregua con los holandeses que permitiese al ejército de Flandes dejar de combatir en dos frentes ${ }^{54}$. Para ello era necesario asegurar

R.: «Los aliados de las esperanzas fallidas. La Casa de Austria y los Vasa de Polonia (15981648)», en MARTÍNEZ MILLÁN, J. y GONZÁLEZ CUERVA, R. (coords.): La Dinastía de los Austria. Las relaciones entre la Monarquía Católica y el Imperio. Madrid, 2011, 3 vols., vol. II, pp. 997-1021, p. 1016.

52. MAFFI, D.: En defensa del Imperio. Los ejércitos de Felipe IV y la guerra por la hegemonía europea (1635-1659). Madrid, 2014, pp. 21-35. ELLIOTT, El Conde-Duque de Olivares..., pp. 476-500.

53. Carta de Felipe IV para el marqués de Castañeda, 9 de octubre de 1635. AGS, E, leg. 2461. Esta carta emana de las decisiones del CE del 5 de ese mes y recoge en gran parte el voto de Olivares del día 2. Ibidem, leg. 2336.

54. Sobre las negociaciones de esta posible tregua VERMEIR, R.: En estado de guerra. Felipe IV y Flandes, 1629-1648. Córdoba, 2006, pp. 130-134 y ISRAEL, J. I. La República bolandesa y el mundo hispánico, 1606-1661. Madrid, 1997, pp. 256-259.

Ediciones Universidad de Salamanca / @@@ Stud. his., H. ${ }^{a}$ mod., 41, n. 1 (2019), pp. 117-152 
el valle del Mosa - aislando Maastricht- y desde allí enlazar con el Esquenque, plaza clave para controlar el Rin con lo que eso suponía de presión hacia terceros, además de amenazar el corazón de las Provincias Unidas ${ }^{55}$.

De todo ello daba cuenta Felipe IV a sus embajadores ante la corte cesárea en una interesantísima carta de 7 de diciembre explicándoles las consecuencias positivas que el momento ofrecía pues Colonia podría verse forzada a dejar su neutralidad; el elector de Brandemburgo, su alianza con holandeses y, además, no era descabellado pensar que éste, Sajonia y el duque de Neoburgo «para que entretanto se declara quién ha de suceder en aquellos estados de Cleves y Juliers, pongan en depósito de S.M. Cesárea las plazas del Rin que ocupan los holandeses». Ahora bien, para que tan halagüeños propósitos se cumplieran eran necesarias dos premisas básicas: conservar el Esquenque y que desde Alemania se acudiera a todo lo necesario sin dilación. Esta segunda premisa implicaba la colaboración de las tropas bajo el mando de Ottavio Piccolomini con el Cardenal Infante en Genep ${ }^{56}$, conseguir «a cualquier precio y en cualquier caso que el emperador y el rey de Hungría, mi hermano, contribuyan con cuanto sea posible» y, por último, que desde Alemania se procurase «comprar a Galasso a cualquier precio», máxime cuando la ofensiva franco-italiana sobre Milán impedía utilizar la plaza de armas lombarda como base de operaciones para acciones en el Imperio ${ }^{57}$.

Esta carta del día 7 de diciembre se completa con otra del 21 emanada de un Consejo de Estado del 27 de noviembre (nótese la tardanza en comunicar lo dispuesto, para desesperación de Olivares) ${ }^{58}$ en la que, copiando casi textualmente el voto del conde-duque, se informaba a los embajadores de que dispondrían ese año de un millón y medio de táleros «a los mejores plazos que sea posible o repartido por meses para el ejército que tengo resuelto y deseo mantener en Alemania para las cosas de Flandes y también para las asistencias de la artillería, conforme lo

55. ISRAEL, J. I. «Olivares, el Cardenal Infante y la estrategia de España en los Países Bajos (1635-1643): el camino a Rocroi», en KAGAN, R. L. y PARKER, G. (eds.): España, Europa y el mundo Atlántico. Homenaje a John H. Elliott. Madrid, 2001, pp. 347-380, pp. 355-356.

56. Piccolomini comandaba una división del ejército imperial, bajo el mando de Viena, pero financiada por Felipe IV. Cada año este contingente se pactaba entre Viena y Madrid pues, al acabar la campaña, abandonaba los Países Bajos para invernar en tierras del Imperio. Al ser un ejército «alemán» los electores católicos y muchos de los consejeros del káiser pensaban que debía actuar contra los enemigos de éste - incluida Francia - pero no contra las Provincias Unidas como deseaba Madrid. Sobre este particular, ELLIOT'T y NEGREDO, Memoriales y cartas, II..., carta 3, notas 3 y 4 .

57. Los entrecomillados proceden de AGS, E, leg. 2461. Cfr. GÜNTER, Die HabsburgerLiga..., pp. 454-455.

58. La minuta de esta carta en AGS, E, leg. 2461. El CE de noviembre en ídem, leg. 2336.

Ediciones Universidad de Salamanca / 요 Stud. his., H. ${ }^{a}$ mod., 41, n. 1 (2019), pp. 117-152 
concertó el marqués de Castañeda, o como sea posible y a satisfacción del rey de Hungría expresamente» ${ }^{59}$.

En el ínterin, y aún antes de recibir tales indicaciones, Castañeda había negociado con el futuro Fernando III apostando por convencer a los imperiales a fuerza de dinero, o por mejor decir, con promesas de dinero. De hecho, don Sancho de Monroy, desdiciéndose de anteriores informes, escribía en noviembre informando de que había prometido aportar dos millones de táleros para el año siguiente con el objeto de lograr unas capitulaciones beneficiosas para la Monarquía ${ }^{60}$.

Cuando tales informaciones llegaron a Madrid (al poco de haberse remitido las dos cartas recién citadas) causaron estupor y don Gaspar de Guzmán no dudó en destapar la caja de los truenos en su voto en el Consejo de Estado de 6 de enero de 1636. A las sospechas de que no se podría defender el Esquenque - lo que implicaba el fin de todos los sueños en torno a una posible tregua - y las negativas noticias que se recibían de Milán, se sumaba ahora el resquemor ante la, a sus ojos, pasividad de las tropas aliadas; resquemor que los memoriales presentados por el embajador imperial, que exigía saber qué se iba a obrar ese año contra Francia y dónde estaba el dinero prometido a su señor, no contribuían a calmar ${ }^{61}$. Antes más, lo acrecentaban haciendo que se le contestara remitiéndole a los informes de los embajadores españoles, lo que producía a su vez una sensación de engaño que el conde de Schönburg se apresuraba a trasmitir a Viena ${ }^{62}$.

Todo ello caló en el ánimo del valido quien adivinaba tras estas peticiones unos intereses espurios muy claros. De ahí que lo expusiera en voz alta en el Consejo de Estado ${ }^{63}$ :

59. Carta de Felipe IV (minuta) para Oñate y Castañeda. AGS, E, leg. 2461. El CE del que emana es el citado en la nota anterior.

60. Castañeda había logrado que Oñate liberase 100.000 florines en agosto para el ejército imperial como muestra de buena voluntad y para convencer al rey de Hungría de la viabilidad de la alianza. Bajo esta influencia don Sancho de Monroy acudió a negociar a principios de septiembre a Nördlingen y Donauwörth con el monarca prometiendo lo aquí referido. ERNST, Madrid und Wien 1632-1637..., p. 196.

61. El 9 de septiembre el emperador había escrito a su embajador en Madrid indicándole que no podría continuar con la guerra en apoyo de la Monarquía si no se incrementaba su pensión mensual de 50.000 florines. Veinte días después volvía a escribir a Schönburg recordándole la importancia de este subsidio y que explicitase las maniobras españolas de diversión en Francia. HHStA, Staatenabteilungen. Spanien. Diplomatische Korrespondenz, Karton 22. Estas instrucciones están en la base de los dos memoriales presentados por el diplomático a Felipe IV.

62. Cfr. CE de 8 y 24 de diciembre. AGS, E. leg. 2336; ERNST, Madrid und Wien 1632$1637 \ldots$, p. 192.

63. Las citas que a continuación se ofrecen proceden de AGS, E, leg. 2337, voto del condeduque en el CE de 6 de enero de 1636 (no del día tres como anota Ernst, p. 195n).

Ediciones Universidad de Salamanca / @®@@ Stud. his., H. ${ }^{a}$ mod., 41, n. 1 (2019), pp. 117-152 
«El estado de las cosas de Alemania es, al parecer del Conde Duque, sumamente trabajoso y, sin duda, a su juicio, los ministros proceden tan llenos de sus particulares intereses y ambiciones que de ninguna manera se puede hacer fundamento de nada de cuanto se tratare con ellos. Y, a su parecer, la razón principal en que se funda una proposición desaforada como pedir dos millones de táleros aquellos que se contentaban con ocho meses a 40.000 florines cada uno, en que va a decir un millón y quinientos mil escudos de diferencia, no se funda en otra cosa que en querernos espantar para que vengamos en cualquiera paz o venir ellos en ella diciendo que no los hemos asistido con lo que les era inexcusable» ${ }^{64}$.

Acusando a continuación sin ambages a los culpables de esta estrategia y la necesidad de acotarla. De hecho, confesaba a Felipe IV que:

«si esperara que pudiéramos hacer una paz segura con franceses por no estar expuestos a las sinrazones y demasías de los alemanes, aunque la paz fuera mala, viniera en ello porque, verdaderamente se dejan sentir mucho sus sinrazones que se reciben de los más propios y obligados. Y confiesa a V.M. que le hace horror de ver que en su Majestad Cesárea y en el señor Rey de Hungría haya tan buena intención y tan pura y tanto afecto a V.M. y que cuantos ministros tienen gobiernen las cosas enderezadas a sus intereses sin ninguna atención ni consideración a la de V.M. ni a las de sus mismos amos - que son inseparables - y que pase lo que pasa en su milicia enriqueciéndose los cabos y pasando necesidad sus amos».

Don Gaspar, después de despacharse a gusto con los alemanes, pasaba a diseccionar lo pactado por Castañeda, considerándolo una quimera inalcanzable pues «de ninguna manera tenemos medios para esta asistencia». Y es que, aunque se dejase de acudir a todo lo demás, no habría de dónde sacar tanto dinero y, sobre todo, que no era ésa cantidad que se pudiese remitir sin destino cierto, Y aquí radicaba el nudo de la cuestión. Olivares recordaba al embajador que no hacía mucho se había permitido informar de la imposibilidad de fiarse de sus aliados «aconsejando que no se capitulase» para lo cual Monroy había razonado,

«que si hubieran menester sus armas para el Imperio, aunque hayan capitulado mil veces no lo cumplirán y que si no las hubieren menester, las darán aunque no hayan capitulado».

64. Para la conversión de monedas, no siempre exacta en los cálculos de Olivares, véase RODRÍGUEZ HERNÁNDEZ, A. J.: «Las limitaciones de la paz: Diplomacia y colaboración económico-militar entre España y el Imperio en torno a la paz de Westfalia (1644-1659)», en MARTÍNEZ MILLÁN y GONZÁLEZ CUERVA (coords.), La Dinastía de los Austria... T. II, pp. 1355-1386, p. 1359, nota 16.

Ediciones Universidad de Salamanca / అ@@ Stud. his., H. ${ }^{a}$ mod., 41, n. 1 (2019), pp. 117-152 
Oído esto, ahora el valido no sabía a qué atenerse pues Castañeda en su último correo se desdecía y prometía grandes logros de verificarse los acuerdos mencionados. Y, en uno de sus típicos monólogos, el de Guzmán confesaba con amargura que:

«Este es, señor, de los peores negocios que es posible ofrecerse en el mundo, o el peor. Porque conforme a su proposición moderada se arruina a millón y medio en un año y conforme a la alta, más de dos. Y, si no los damos, somos perdidos y, si los damos, no nos ganamos, si no que en todo será lo que ellos hubieren menester en primer lugar para sus fines particulares e intereses y no dice de sus majestades, sino de sus ministros y cabos».

Con todo, Olivares no caía en el derrotismo fácil. Fiel a su estilo, tras el desahogo planteaba una política de acción que pasaba por ordenar a los embajadores que capitulasen lo que pudieran advirtiéndoles, en especial a Castañeda, de cuánto se extrañaba el rey católico del proceder de su ministro. Por eso sugería que se obligase al rey de Hungría a poner 16.000 hombres, al menos, en Westfalia con cabos a entera satisfacción del Cardenal Infante y dispuestos colaborar con él desde primeros de mayo. Asimismo, se apremiaba al rompimiento con Francia «siendo intolerable el disimular más esta parte» y que tanto el rey como el emperador jurasen - si no se pudiere en público, al menos en privado - todo lo que se capitulase ${ }^{65}$. Ahora bien, no sin cierto cinismo, el conde-duque volvía a reconocer que la cantidad pedida era inalcanzable y según sus cálculos a lo más que podría llegarse sería a un millón de florines y:

«Si no se contentasen con esto es menester ajustarse a hacer lo que quisieren, procurando abaratar pero no dejando por nada de ajustar la materia, porque va en ella tanto como perdernos sin remedio si no se hace».

La opinión del conde-duque fue sustentada en pleno por el Consejo y ratificada por el monarca que tan sólo hizo hincapié en que se insistiera en la presencia de su cuñado al mando del ejército recalcando a los embajadores «que por ningún precio dejen la negociación» ${ }^{66}$.

Mientras en Madrid se discutían estas actuaciones, en Alemania, Castañeda capitulaba por su cuenta un nuevo tratado que sustituyera al de Ebersdorf. El acuerdo se firmó el 30 de diciembre de 1635 y estipulaba, entre otras cosas, que Fernando II autorizase la recluta por parte de la corona hispana de 20.000 infantes y 5.000 jinetes en el Círculo renano. Ejército, que, tras haber jurado a Felipe IV,

65. Las fuerzas acordadas para entrar en Francia deberían componerse de 24.000 infantes, 12.000 corazas y 4.000 caballos ligeros bajo el mando del rey de Hungría, ante la poca fiabilidad de Galasso.

66. Resolución real al margen de la consulta del CE de 6 de enero de 1636. AGS, E, leg. 2337.

Ediciones Universidad de Salamanca / 요 Stud. his., H. ${ }^{a}$ mod., 41, n. 1 (2019), pp. 117-152 
sería cedido libremente al rey de Hungría para que operase en Alemania o Francia comprometiéndose éste a procurar los alojamientos necesarios. Además, los embajadores pactaban una subvención mensual de 100.000 táleros mientras durase la guerra con Francia ${ }^{67}$.

Con él se suponía que ambas ramas tendrían mucho más claro su proceder e iniciarían la campaña con objetivos comunes, pero el desarrollo de la misma demostró que esa pretensión era una quimera y la constatación de su fracaso marcó un punto de inflexión que el devenir de los acontecimientos los años siguientes no hará sino constatar.

Las noticias de la firma del nuevo tratado llegaron a la capital hispana a principios de febrero, justo después de que Olivares hubiera escrito una dura carta de reproche al embajador cesáreo, conde de Schönburg, por el desamparo con que los imperiales habían dejado los diferentes frentes abiertos del rey católico. Aún con todo, se realizó un importante esfuerzo hacendístico para conseguir cubrir, si no al completo, sí gran parte de las peticiones vienesas y así para mediados de marzo se había conseguido firmar un asiento de un millón ochocientos mil escudos para Alemania ${ }^{68}$, dato del que se hacía partícipe al Cardenal Infante aunque siempre pendía en el aire la pertinaz desconfianza hacia el aliado imperial ${ }^{69}$. Desconfianza que el hermano del rey desde Bruselas alentaba en diferentes cartas durante la primavera de ese año. De hecho, el 2 de mayo responsabilizaba directamente a sus aliados de la pérdida del Esquenque ya que:

«lo han dejado perder sin que mis intenciones y protestas le haya obligado a mover un hombre diciendo que tienen orden precisa de no romper con los holandeses por ningún accidente. Viendo esto y los buenos deseos del marqués de Grana que es quien mandaba aquellas tropas despaché a Viena, quejándome de éste, tres correos, pero no ha vuelto ninguno habiendo dos meses que partieron de aquí» ${ }^{70}$.

67. El acuerdo lo firmaron Castañeda y Oñate pero todo parece indicar que su negociación fue obra en exclusiva del marqués. ERNST, Madrid und Wien..., pp. 197-199. Este tratado, casi con toda seguridad, no fue nunca ratificado en Madrid de ahí que no lo reproduzca Abreu ni lo hayamos encontrado ni en AGS ni en AHN.

68. «Voto del Conde Duque para verse en el CE, 15 de marzo de 1636». AGS, E, leg. 2337.

69. «También se despacha a Alemania, con mucho, mayores provisiones con que, si cumplen, se puede esperar en Dios ha de tener vuestra Alteza un gran año. Aquí nos han cortado las alas muchos accidentes juntos y, sobre todo, lo que crece lo de Alemania con lo que han asentado los embajadores. Y no se puede negar que, si ellos cumplen lo que ofrecen, se asegura mucho nuestro partido y, si no, no sería de cordura desembolsar». Olivares para el Cardenal Infante, 14 de marzo de 1636. Editada en ELLIOT'T y NEGREDO (eds.) Memoriales $y$ cartas..., carta $\mathrm{n}^{\circ} 12$.

70. Don Fernando para Felipe IV, BCLM, CL, t. 3, f. 91.

Ediciones Universidad de Salamanca / @®@@ Stud. his., H. ${ }^{a}$ mod., 41, n. 1 (2019), pp. 117-152 
Tema éste, el de las quejas hacia los germánicos, recurrente tanto en su correspondencia con Olivares como con el rey y que se habían iniciado ese año nada más terminar la campaña por los lugares elegidos por las fuerzas aliadas para invernar. En este sentido, don Martín de Axpe ya había avisado a la corte a finales de enero sobre el particular y Olivares confesaba atónito que no acababa de comprenderlo ${ }^{71}$.

Pero si Madrid no se fiaba de Viena, a la inversa la situación era similar ya que Fernando II, al informar a su embajador de la firma del tratado, le había manifestado con duras palabras su sospecha de que los españoles no cumplirían y, en tal caso, Schönburg habría de amenazar con que el Imperio se vería obligado a firmar la paz con Francia ${ }^{72}$. Retengamos estos datos porque nos muestran que, apenas siete meses después de haberse iniciado la guerra contra los Borbones, el gobierno madrileño ya desconfiaba enormemente de las decisiones tomadas por la rama austriaca (y viceversa) pensando que tras muchas de sus pretensiones se escondían motivaciones oscuras que buscaban, en el fondo, su ruina. Y, por si fuera poco, a todo esto se sumaba algo ya apuntado como era que el emperador no había publicado ningún manifiesto ni edicto explicando el porqué de su enfrentamiento con el rey Cristianísimo y legitimando públicamente su postura. Inacción que pesaba sobremanera en los ánimos de muchos consejeros de Felipe IV - y en el mismo rey - quienes, al sumar esta pasividad y los hechos de armas acaecidos en la última campaña, llegaban a la conclusión de que en Viena no se velaba en absoluto por los intereses de la Casa de Austria encarnados en la política de su mayorazgo, el rey Católico. La ruptura de relaciones entre el káiser y Luis XIII, verificada en marzo, algo relajó esta desconfianza, pero la negativa de Fernando II a emitir una declaración de guerra formal, a pesar de las presiones hispanas e, incluso, de su propio hijo, la volvió a acentuar ${ }^{73}$.

71. «[...] las tropas de la Liga Católica han ocupado el País de Tréveris y llegado los polacos y otra caballería cerca de Luxemburgo, con el conde Coloredo, en número de 14.000 caballos a pedir cuarteles a su Alteza; y que aunque se procuraba entrasen en Francia, como no tienen artillería no se podrán mantener ni ocupar puesto considerable». Frente a esto Olivares respondía que «el conde-duque no se desavendría de ninguna manera de que pusiese las espaldas a los estados con tal que tomasen puesto desde donde pudiesen socorrer y alojarse y que de los estados de Flandes y Borgoña se les suministren víveres por su dinero y aunque los pagase V.M., pero dejar alojar en los propios estados y correrlos es lo impracticable, injusto y de mal gobierno", CE de 18 de abril de 1636 (punto 46) sobre una carta de don Marín de Axpe de enero de ese año, AGS, E, leg. 2051, 51.

72. El emperador interrogaba a su legado preguntándose «¿De qué forma seremos estafados esta vez acerca de este necesario subsidio?», ERNST, Madrid und Wien..., p. 198. No deja de ser curioso que el káiser amenazase con firmar la paz con Francia cuando todavía no le había declarado la guerra.

73. El 14 de junio de 1636 el rey de Hungría había escrito a su padre planteando la oportunidad de realizar un manifiesto en que se declarase al rey de Francia como enemigo del Imperio. Tan sólo dos días más tarde el emperador le contestaba declinando tal posibilidad

Ediciones Universidad de Salamanca / @®@@ Stud. his., H. ${ }^{a}$ mod., 41, n. 1 (2019), pp. 117-152 
Empero estas incertidumbres, desde muy pronto se iniciaron las gestiones para la recluta y alistamiento con vistas a desarrollar una campaña que solventase los errores de coordinación apreciados en la del año anterior como fue el caso de la Valtelina ${ }^{74}$. Por ello y en consonancia con lo acordado, Oñate fue liberando dinero de la caja de la embajada a lo largo del primer semestre de 1636 pero sus pagos se hacían a un ritmo mucho menor del que Fernando II y su hijo deseaban y con un rendimiento muy por debajo del que el diplomático español pretendía ${ }^{75}$. Esa es la razón de que los diferentes cuerpos de ejército alemanes no acabasen por completarse y acudir a los diversos escenarios en las fechas demandadas ${ }^{76}$. El desencuentro se barruntaba y sólo parecía cuestión de tiempo que se concretase. Y esta concreción tuvo lugar en el decurso de la campaña.

Según entendían Felipe IV y sus ministros, el acuerdo de diciembre implicaba que el esfuerzo principal de guerra debía concretarse a lo largo del curso medio de Rin y ser realizado por las tropas de Galasso y las del rey de Hungría atacando la Borgoña ducal y, si fuese posible, su capital, Dijon. Mientras, otros contingentes colaborarían con el Cardenal Infante en una ofensiva sobre las Provincias Unidas que impidiese la caída del Esquenque ${ }^{77}$. Por el contrario, en Viena se esperaba que el

pues cerraría la puerta a un posible entendimiento entre las dos coronas, todavía factible a sus ojos. En agosto, el futuro Fernando III volvía a insistir y esta vez remitió un borrador del texto a publicar. De nuevo su padre rechazó la iniciativa pues no sólo introdujo enormes cambios en el texto propuesto, sino que rehusó firmarlo, por lo que, en realidad, nunca existió una declaración formal de guerra entre Fernando II y Luis XIII. HHStA, Reichshofkanzlei, Kriegsakten, 117. ff. 47-49 y 74-77 y Friedensakten, 18, f. 177. Cit. en MALETTKE, «France's Imperial Policy...», pp. 183 y 185.

74. MAFFI, D.: «Confesionalismo y razón de estado en la Edad Moderna. El caso de la Valtellina (1637-1639)», Hispania Sacra, 57, 2005, pp. 467-489, p. 476.

75. En un informe emitido el 25 de julio Oñate reportaba que casi medio millón de florines habían sido transferidos en diferentes partidas aunque no en todas ellas quedaba claro el destino final. Sobre todo, porque se sabía que unos cuantos miles de táleros se habían desviado, acabando en las arcas del elector de Sajonia. ERNST, Wien und Madrid..., pp. 224-227 y 275.

76. En la correspondencia del Cardenal Infante tanto con su hermano como con Olivares son continuas las quejas sobre «la flema» de los alemanes llamados a colaborar con él durante la primavera de 1636. Además, la falta de fondos obligaba a estas unidades - cuya composición era muy variopinta, con polacos, croatas, sajones, bávaros, etc. - a vivir sobre el terreno y pedir cuarteles y manutención en los territorios del rey católico, algo que tanto Madrid como Bruselas rechazaban de plano. Hasta el mismísimo Matteo Galasso, comandante en jefe de las fuerzas renanas del emperador, envió a Flandes a su principal oficial de enlace, el coronel Sebastián Pelegrino acompañado del barón de Enquenvolt "pidiendo caballería, infantería y dinero con que hacer diversión en Francia», algo que sorprendió a don Fernando quien sorteó la insólita petición como pudo. AGS, E, leg. 2051, 51.

77. A diferencia del año anterior, el tratado franco-neerlandés de 1636 no contemplaba ninguna invasión francesa de los Países Bajos. Cfr. ESTEBAN ESTRÍNGANA, «Olivares y el Cardenal Infante en el gobierno de Flandes...». 
ejército de Flandes, reforzado por numerosos contingentes bajo banderas imperiales pero costeados en todo o en parte por la Monarquía, realizase una profunda penetración en Francia desde el norte a la vez que desde el sur otras divisiones españolas cruzasen el Bidasoa obligando a Richelieu a acudir a diferentes frentes que se verían ampliados por la presión sobre Lorena-Renania. Se temía, y mucho, que tras el tratado de Wismar entre Suecia y Francia, las tropas escandinavas reemprendieran su ofensiva en la zona oriental del Imperio por lo cual los contingentes del frente occidental debían estar atentos a su posible traslado hacia el este ${ }^{78}$.

Esta divergente percepción de cómo hacer la guerra se acrecentaba cuando más allá de los mapas del alcázar, los cabos debían tomar decisiones sobre el terreno. Era el caso de don Fernando que, a despecho de las órdenes recibidas y como consecuencia de la capitulación del fuerte Esquenque en abril de 1636, decidió mantenerse a la defensiva en su frente neerlandés y, sin mucha convicción, preparar un ataque a Francia. En su decisión operaron, no sólo los sucesos recién citados sino también, por un lado, la convicción de que las heterogéneas fuerzas de sus aliados ${ }^{79}$ nunca romperían con las Provincias Unidas y, por otro, la constatación de que, tras el esfuerzo bélico que había supuesto para el ejército del príncipe de Orange la campaña del Schenkenschans éste no podría lanzar ninguna nueva ofensiva durante ese año ${ }^{80}$.

Pero mientras los hispano-imperiales no terminaban de ponerse de acuerdo, Condé se adentró en la Borgoña - rompiendo los tratados de neutralidad garantizados por la Confederación Helvética que hasta entonces se habían respetado- y asedió su capital, Dole ${ }^{81}$. Fue entonces cuando el hermano de Felipe IV se vio forzado a iniciar una ofensiva sobre Francia pues, de no hacerla, Viena le reclamaba todas las tropas trasferidas para ocuparlas en otros escenarios. Es éste, y no otro, el contexto

78. NEGREDO, La Guerra de los Treinta Años..., p. 218. Por el acuerdo se estipulaba que París subsidiaría a Estocolmo con un millón de libras anuales durante tres años más medio millón por atrasos a cambio de su cooperación militar para luchar contra «los imperiales y españoles, sus perpetuos enemigos». ABREU Y BERTODANO, Colección de los Tratados de Paz de España..., III, pp. 173-178. No es cuestión baladí remarcar que este tratado, firmado el 20 de marzo en Wismar, fue ratificado por Luis XIII el 15 de abril (WILSON afirma que se firmó el 30 de marzo y se ratificó el 11 de mayo, Europe's Tragedy..., p. 580, pero no indica sus fuentes) justo un día antes de la firma del nuevo tratado con las Provincias Unidas.

79. Las fuerzas que debían colaborar con el gobernador general eran realmente heterogéneas pues se contaban entre ellas: los imperiales ya citados de Piccolomini; las unidades de la antigua Liga Católica dependientes de Baviera y comandadas por Jan de Weert y las del duque de Lorena bajo el mando de su tío el obispo de Verdún. Todas ellas, aunque independientes de facto, durante la campaña se hallaban, de jure, bajo la superintendencia militar del príncipe Tomás de Saboya, en ese momento al servicio de Felipe IV y subordinado del Cardenal Infante.

80. ISRAEL, La república holandesa..., p. 157.

81. Para esta ofensiva, PARROTT, D.: Richelieu's Army. War, Government and Society in France, 1624-1642. Cambridge, 2004, pp. 119-121 
de la llamada «campaña de Corbie», operación nunca diseñada para conquistar la capital gala sino forzada por los acontecimientos y generada por la presencia de los contingentes aliados que no se podían desaprovechar, y el temor a la pérdida del Franco Condado ${ }^{82}$. Pero en la mente tanto del gobernador general de los Países Bajos como de Olivares se contemplaba tal acción como un esfuerzo secundario que debería acompañar, como diversión, al principal a desarrollar por el ejército de Galasso. Esta unidad se presumía estaría formada por 36.000 infantes y 11.000 caballos a los que habrían de sumarse nuevas fuerzas a lo largo de la campaña ${ }^{83}$.

El problema era que esta unidad había fracasado en la defensa de Saverna y no se había movido en toda la primavera de sus bases. Según sus mandos por falta de financiación - lo que había propiciado la deserción de la caballería polaca- y según los españoles por motivaciones más espurias. Y sin su colaboración, el resto de empeños perdían su sentido. De ahí las acres recriminaciones entre los dirigentes imperiales y los embajadores españoles.

En efecto, durante el verano de 1636 don Íñigo Vélez de Guevara y el rey de Hungría mantuvieron una tensa correspondencia. Éste le acusaba por carta de tener dinero a su cargo y no querer liberarlo cuando, según él, tanto había hecho por la causa de Felipe IV. De seguir así, le amenazaba, no tendría más remedio que informar a su soberano de su nula cooperación ${ }^{84}$.

Si con esta misiva el monarca húngaro pensaba iba a amedrentar al noble castellano, era señal de que no conocía a su interlocutor. Oñate, el mismo día que la recibió, se apresuró a contestarle sin morderse la lengua e incidiendo en la cuestión de fondo, que no era otra que el incumplimiento de las capitulaciones acordadas ya que la situación no era tal y como la veían los germanos sino muy al contrario. De hecho, don Íñigo le recordaba que la entrada en Francia del Cardenal Infante nunca se había pactado y que era una decisión arriesgada, tomada sólo con vistas a

82. WILSON, Europe's Tragedy..., p. 563-565, parece desconocer la presión imperial sobre el Infante para que los contingentes reunidos se devolviesen si no se atacaba Francia además de atribuir a Olivares una decisión que fue, en realidad, de don Fernando ante la crítica situación del Franco Condado. La valoración de STRADLING sobre esta ofensiva carece de cualquier constatación documental. La correcta valoración de esta campaña en ESTEBAN ESTRÍNGANA, «Olivares y el Cardenal Infante en el gobierno de Flandes...».

83. CE, 12 de abril de 1636 con informes de Castañeda de febrero. AGS, E, leg. 2337.

84. "Yo sé que tenéis provisiones necesarias para todo pues vengo avisado del embajador del emperador mi señor que tiene en España, de que el rey, mi hermano, ha remitido dos millones y medio de Reichstalleros para Alemania [...] Todo esto he querido deciros y poner en vuestras manos mi honra, mi crédito, la conservación o pérdida de estas nuestras provincias y, por consiguiente las de vuestro rey. Y si sobre todo esto no hubiere ningún remedio, seré esforzado a escribir al rey mi hermano la causa de todo esto y que el emperador mi señor ni yo tenemos culpa de ello». Copia de carta del rey de Hungría para el conde de Oñate, 16 de julio de 1636. AGS, E, leg. 2337. 
ayudar a la campaña imperial. Campaña que no cumplía con los objetivos fijados pues «se ve lo poco que obra el ejército de Galasso ${ }^{85}$ » dejando claro que mantener una mera posición defensiva en el Rin no era razón suficiente para recibir los subsidios prometidos ya que incumplía el punto sexto del tratado de diciembre de 1635 . El rey católico - le recordaba - no exprimía a sus vasallos para que los generales imperiales estuvieran inactivos. Asimismo hacía hincapié en que las aportaciones españolas a la defensa del Imperio habían sido - y eran - muy cuantiosas y mayores de lo que «contribuyen al emperador para esta guerra los reinos y provincias que Dios le ha dado». Por fin, el de Oñate concluía su respuesta con una muestra clara de altanería al escribir que:

«Al rey, mi señor, doy cuenta en todos mis despachos de lo que aquí se hace, y así no podrá hacerle novedad nada de lo que V.M. fuese servido avisarle ni yo dejar de tener por dicha particular el dar menuda cuenta de mis acciones»

Frase con la que, además de demostrar no amilanarse por amenazas veladas, dejaba de manifiesto que nada se hacía sin el consentimiento de Felipe IV.

Cuando este intercambio epistolar se supo en Madrid - por mano del embajador imperial - Olivares ponderó la situación con calma reprochando al de Oñate sus formas, pero no el fondo del asunto pues los recelos de don Íñigo eran compartidos por los dirigentes madrileños ${ }^{86}$. De hecho ya antes no se habían prestado oídos a las peticiones del embajador imperial para que se dejasen «a libre disposición del señor rey de Hungría las provisiones que V. Majd. ha envido para el sustento del ejército y también las tropas de V.M. que han quedado en Alemania y que V.M. sea servido de ordenarlo así al conde de Oñate» ${ }^{87}$. Antes al contrario: en las instrucciones cursadas a los embajadores a principios octubre de 1636 se les ordenaba que el dinero recibido tuviesen claro debía servir para financiar una ofensiva que obrase

85. La desconfianza hacia Galasso ya la había alimentado Castañeda a finales de 1635 al informar que quizá este general no estuviera haciendo todo lo que debiera por estar en connivencia con el obispo de Viena y a través de él, con el Papa. Ésta era una de las razones por las que desde España se exigía que el comandante en jefe del ejército imperial fuese el rey de Hungría. CE, 11 de enero de 1636, AGS, E, leg. 2337. Las excusas de este general las presentó el conde de Schönburg, en un memorial de 4 de febrero de 1637, AGS, E, leg. 2052, 57.

86. ERNST, Wien und Madrid..., pp. 257-259 y siguiéndola, VERMEIR, En estado de guerra..., pp. 142-143 opinan que Olivares montó en cólera al enterarse de esta noticia. Evidentemente a Olivares le contrarió que Oñate no hubiera proporcionado los subsidios, pero entendió sus razones: «No me parece que se puede negar que, si bien debió de decir lo cierto el conde de Oñate, le escribió con sobrada gallardía y con poca prudencia», voto del Conde Duque, s.f. pero de principios de septiembre ya que el papel del conde de Schönburg quejándose de la respuesta de Oñate lleva fecha del 4 de ese mes. AGS, E, leg. 2337.

87. CE, 8 de agosto de 1636. AGS, Est, leg. 2337.

Ediciones Universidad de Salamanca / @®@@ Stud. his., H. ${ }^{a}$ mod., 41, n. 1 (2019), pp. 117-152 
«dentro de la Francia; y, si fuere posible tomar Dijon y el ducado, se haga en primer lugar; y se ajuste preciso número de gente que haya de campear dentro de Francia y en ésta se señale número de gente que haya de acudir donde ordenare el Infante, mi hermano, y a cualquiera llamamiento suyo. Y ajustaréis las asistencias las cuales se han de pagar por manos de ministros míos conforme a lo mismo que se asentare, aunque sean por libranzas del señor rey de Hungría con el vidit del embajador...» ${ }^{88}$.

Insistiendo en que desde Madrid se tenía como premisa inexcusable el que las aportaciones monetarias fueran fiscalizadas por la embajada española y nunca entregadas directamente a los cabos o ministros imperiales, incluido el rey de Hungría y el mismísimo emperador. Esta decisión, que compartían el rey, valido y consejeros, chocaba frontalmente con los deseos de Fernando II y sus colaboradores y, aunque el conflicto se personificó en la gestión del conde de Oñate, en realidad atravesaba todo el entramado diplomático establecido entre las dos tramas Habsburgo.

La falta de cortesía de Oñate, no obstante, no fue lo único que molestó a Olivares. Según avanzó el otoño de 1636 se fueron conociendo en Madrid las cuentas de aquella embajada y, decisiones políticas aparte, éstas ofrecían «ya a primera vista muchos errores y datos vagos» según el valido ${ }^{89}$. Si a esta imprecisión le sumamos la presión imperial, plasmada en una serie de quejas y escritos elevados por el embajador cesáreo en Madrid denunciando la actuación de don Íñigo Vélez de Guevara, entenderemos la decisión real de hacer alguna demostración con este aristócrata aprovechando que regresaba a la Península tras el convento electoral de Ratisbona, en donde salió elegido el rey de Hungría como rey de romanos. Porque, a fin de cuentas, como decía el valido «se debe decir al conde que no tuvo razón en escribir con tanto desahogo al rey de Hungría [...] pues el escribir picanzones no es lenguaje para con superior» ${ }^{90}$.

Así, en primera instancia se le ordenó se quedara en Barcelona - puerto al que había llegado vía Génova - con vistas a enviarlo de nuevo como diplomático a Italia. Para impedirlo, Oñate elevó un memorial el 13 de septiembre de 1637 alegando su falta de salud para poder cumplir este nuevo cometido y rogando se le permitiese entrar en la corte «a besar sus reales pies después de tan larga peregrinación». Vista su petición, el rey, previa consulta secreta del cardenal Borja y el marqués de Villahermosa, le permitió, a mediados de octubre, acercarse «a la Alameda o a Barajas o

88. Carta para los embajadores en Alemania, 4 de octubre de 1636. A.G.S Est, leg. 2338, que sigue al pie de la letra el voto de Olivares para el CE de $1^{\circ}$ de octubre, que se encuentra en Ibidem, leg. 2051, 214.

89. Las cuentas de este periodo las analiza ERNST, Wien und Madrid..., pp. 224-231, de donde hemos extraído también la cita que se puede ver en el CE, 18 de noviembre de 1636, AGS, E, leg. 2337.

90. Voto de Olivares, CE, 12 de noviembre de 1636, AGS, E, leg. 2337. Citado por ERNST, Madrid und Wien..., p. 257. 
a Canillejas o a Carabanchel pues allí podrán ir los médicos sin dificultad y volver». No contento con esto, don Iñigo insistió en entrar en Madrid y el 9 de noviembre Felipe IV le concedía:

permisión para que pueda entrar en su casa y curarse sin recibir visitas ningunas ni estar y andar en público y después de haberse curado ordenaré dónde ha de ir pues siempre ha de ser con el presupuesto con que le di licencia para salir de Barcelona9 ${ }^{91}$.

De esta forma, se simbolizaba el enojo real y se satisfacía al embajador imperial que podía escribir a su señor sobre esta demostración ${ }^{92}$. Ahora bien, Felipe IV sabía que Oñate se había limitado a cumplir con su obligación y que era, además, el único gran experto en el Imperio con que contaba el Consejo de Estado ${ }^{93}$. De ahí que, en vez de defenestrarlo, a los pocos días su voz volviese a ser escuchada en el máximo órgano polisinodial y, más adelante, se le permitiera tomar posesión de su plaza como presidente del Consejo de Órdenes, puesto que había obtenido antes de marchar a Alemania en $1633^{94}$. En esta misma línea cabe recordar que ya en 1624 se había utilizado una estrategia muy similar - y con el mismo protagonista - en aquella ocasión para dar satisfacción al duque Maximiliano de Baviera95.

91. Los últimos entrecomillados proceden todos de AGS, E, leg. 2760. Las dificultades de Oñate en su retorno a la corte se recogen en Noticias de Madrid, pp. 211, 220 y 238 y de ellas, tiempo después, se harán eco los Cargos de Andrés de Mena, cfr. ELLIOTT, J. H., DE LA PEÑA, JOSÉ F. y NEGREDO, F. (eds.): Memoriales y Cartas del Conde Duque de Olivares, Madrid, 2013, vol. I, t. II, p. 399, n. 18.

92. De hecho, el 12 de mayo, Schönburg escribía a su señor que Oñate no era querido en la corte. ERNST, Madrid und Wien..., p. 256-57.

93. Los jesuitas, siempre bien informados, no dudaban que el castigo habría de durar poco y el 16 de noviembre escribían: «Tres días ha que entró en la corte después de su larga peregrinación, el conde de Oñate; no ha hasta ahora besado a S. M. la mano, mas presto se le dará licencia». Cartas, t. II, p. 207. En febrero de 1638 el problema se dio por zanjado tras una entrevista con el conde-duque. Idem, p. 338.

94. La negociación del conde de Oñate a principios de 1633 para acceder ir a la embajada a Alemania se puede seguir en AHN, E. lib. 712. El conde, además de un incremento sustancial en su salario y ayuda de costa, solicitó la concesión de la grandeza para su casa, merced, ésta última, que no obtuvo.

95. Con ocasión de los problemas de traslación del electorado imperial que hemos mencionado al principio y la clara significación de Oñate en su contra, Olivares planteó la posibilidad de remitirle una carta de reprensión por haber faltado a las órdenes del rey «y juntamente con ella enviar un embajador mostrándose V.M. disgustado con el conde y dando a entender con esta demostración de quitarle de allí, al mundo, al emperador y duque de Baviera que su ánimo de V.M. ha sido favorecer al duque» y un poco más adelante argumentaba que si de esta manera se lograba salvar la reputación no sería mala solución, pues «aunque el conde no haya merecido culpa (como es cierto, pues en la sustancia no ha errado, sino en el modo y éste sería por pensar que acertaba más) al conde podría V.M. hacerle mercedes acá después». Voto del conde de Olivares para el CE de 8 de abril de 1624. BCLM, CL, t. 47.

Ediciones Universidad de Salamanca / అ@@ Stud. his., H. ${ }^{a}$ mod., 41, n. 1 (2019), pp. 117-152 
Y es que, como apunta Ernst, lo que en realidad se había dirimido eran dos maneras de entender la forma de sufragar el apoyo germánico a la causa hispánica. La más liberal y, hasta cierto punto, descontrolada del marqués de Castañeda y la mucho más rígida y fiscalizadora del conde de Oñate. La primera era más estimada por gran parte de los aliados ${ }^{96}$ pero, de no ofrecer resultados tangibles, corría el grave riesgo de quedar deslegitimada a los ojos de los gobernantes de la Monarquía, como en breve pasó ${ }^{97}$. La segunda, fruto de la experiencia, podía, en momentos puntuales, ofrecer certidumbres pero era muy difícil de aplicar en un escenario tan voluble e inseguro como el germánico en la guerra de los Treinta Años. Por último, intentar compaginar las dos estrategias teniendo a ambos representantes (que tampoco mantenían una coordinación perfecta) negociando las ayudas era, sencillamente, inviable. De ahí su fracaso ${ }^{98}$.

Pero, affaire Oñate aparte, lo que podemos concluir es que la campaña de 1636 había finalizado arrojando más sombras que luces sobre las relaciones hispanoimperiales. La incapacidad el ejército cesáreo para realizar una incursión en profundidad en Francia, ejemplificada en el fracaso de Galasso ante Saint Jean de Losne ya en octubre cuando, según los informes españoles, se encontraba en superioridad numérica, vino a corroborarlo. De poco sirvieron las explicaciones que el conde de Schönburg presentó en febrero exculpando a este general del fracaso y pidiendo nuevas y más cuantiosas contribuciones ${ }^{99}$. Tanto en Madrid como en Bruselas la idea era cada vez más clara. Y es que, tras los oropeles de la invasión de Francia se

96. Es ilustrativo al respecto el despacho recibido por el conde Schönburg fechado el 16 de enero de 1640 en que se le indicaba que procurase evitar ante Felipe IV y Olivares que Castañeda fuese relevado. HHStA, Staatenabteilungen. Spanien. Diplomatische Korrespondenz, Karton 23.

97. Castañeda será cesado fulminantemente en 1640. CE, 26 de mayo de 1640. AGS, E, leg. 2341. Ya en octubre de 1639 el Cardenal Infante escribía a Olivares unas significativas palabras al respecto: «Conde, es menester poner remedio eficaz en estas cosas de Alemania porque, como corren hoy, ellos y nosotros nos perderemos. Y el primero, en mi opinión, ha de ser sacar de allí al marqués de Castañeda que, tantos años de embajada, le tienen más alemán de lo que hemos menester y, después que el conde de Oñate salió de allí, hacen burla de nosotros y nos quitan el dinero que, como si sobrara, le da el marqués al Emperador cuanto le pide». ELLIOTT y NEGREDO, Memoriales y Cartas..., t. II, carta no 118 . También el marqués de Fuente del Torno se quejaba de la gestión de Castañeda como embajador en una interesante carta para el secretario Carnero de 6 de abril de 1640. AHN, E, lib. 712.

98. Fracaso que, con clarividencia, había anticipado mucho antes el duque de Alba en un interesante voto cuando empezó a discutirse el enviar un embajador extraordinario a Alemania. CE, 8 de julio de 1631, AGS, E, leg. 2332.

99. "Que el conde Galasso, no pudiendo, por haber enviado al Lamboy al socorro de Dola con mucha gente, entrar en Francia hasta que se juntase con él la de Prusia, últimamente ha sido obligado por las continuas aguas de 17 días, a alzar el cerco de San Joan de Lona y retirarse y cargar con su ejército al condado de Borgoña hasta que tenga ocasión de volver a entrar en el ducado como tiene orden expresa de hacer». AGS, E, leg. 2052, 57.

Ediciones Universidad de Salamanca / అ@@ Stud. his., H. ${ }^{a}$ mod., 41, n. 1 (2019), pp. 117-152 
escondían enormes contradicciones que el tiempo no contribuyó a disipar. Antes más, la evolución de la guerra las fue acrecentando. En este sentido son más que premonitorias las palabras de don Fernando, el cardenal infante, tanto cuando escribía a su hermano como en lo que le decía al propio Olivares. Al primero le dejaba claro que era necesario:

«escarmentar de los alemanes que tan mal han cumplido lo que han asentado y, particularmente, Galasso. Después de muchas protestas que todos le hicimos, entró en Francia como por cumplimiento pues no estuvo más de 8 días y luego se retiró a Borgoña con pérdida de gente, artillería, bagajes y mucha reputación [...] y todo son excusas muy frívolas y así es menester no fiarse más de esa gente» ${ }^{100}$.

Mientras que al segundo le recomendaba:

«es menester prestar paciencia y tratar del remedio para el año que viene, escarmentando en estos señores alemanes que tan bien nos han dejado empeñar y luego nos han faltado cuando más era menester pues por más instancias que les hemos hecho y protestas, han hecho lo que verás por los despachos [...] teniendo entre infantería y caballería, de todo género, treinta mil hombres y ochenta piezas de artillería y los franceses, el más, se alarga en todo doce mil hombres que son cosas para desesperar y tomar una fuerte resolución sin depender más de esta gente sino fuere el no inexcusable» ${ }^{101}$.

\section{CONCLUSIONES}

Tras el relativo fracaso de los planes de guerra durante 1635-1636 no se volvió a firmar, entre Madrid y Viena, un acuerdo similar a los referidos. Esto no quiere decir que la cooperación se cortase, ni mucho menos, pero se circunscribió al envío de dinero y a la discusión de dónde y cómo emplear las tropas subvencionadas con este dinero sin que se hicieran capitulaciones más o menos solemnes ${ }^{102}$.

Tres fueron las cuestiones más debatidas hasta 1639: en primer lugar la manutención y operatividad del ejército comandado por el condottiero toscano Ottavio

100. Carta del Cardenal Infante para Felipe IV, 6 de diciembre de 1636. BCLM, t. 3, f. 115.

101. Carta del Cardenal Infante para el conde-duque, 6 de diciembre de 1636. Carta ${ }^{\circ}$ 31 de la edición realizada por ELLIOTT y NEGREDO, Memoriales y Cartas...

102. Entre 1637 y 1640 la embajada española en Viena concedió al emperador 1.249.006 florines para el mantenimiento de su ejército, si bien el total remitido a la corte imperial entre marzo de 1637 y julio de 1640 ascendió a casi tres millones de florines. RODRÍGUEZ HERNÁNDEZ: «Financial and Military cooperation...» pp. 579-580. Según ERNST, Madrid und Wien..., pp. 192 y ss. la Monarquía pagó 2,4 millones de florines entre 1636 y 1639 que era la mitad de lo que se había prometido y un tercio de dicha cantidad fue directa para las reclutas propias.

Ediciones Universidad de Salamanca / అ@@ Stud. his., H. ${ }^{a}$ mod., 41, n. 1 (2019), pp. 117-152 
Piccolomini (vid. supra nota 53); en segundo lugar la colaboración de diferentes contingentes pro-imperiales en una posible ofensiva contra Francia y, si fuese posible, contra las Provincias Unidas y tercero, pero no menos importante, la defensa del curso medio y alto del Rin con especial atención a Borgoña y Alsacia. Todas ellas fueron causa de desencuentros y sinsabores.

Y es que, las tropas cesáreas nunca realizaron campaña alguna contra los neerlandeses, a pesar de que hubo momentos más que proclives para hacerlo (por ejemplo cuando el príncipe de Orange asedió Breda en 1637); la defensa de la zona renana quebró estrepitosamente en 1638 tras la caída de Breisach en manos de Bernardo de Sajonia-Weimar sin que el varias veces proyectado ejército de Alsacia-Tirol llegase a tener forma (y mucho menos operatividad ${ }^{103}$ ). De la misma forma, las fuerzas de Piccolomini, después de una colaboración desigual, se retiraron definitivamente del escenario flamenco, en el otoño 1639. Su partida, que respondía a una orden directa y perentoria del emperador tras la derrota sajona en Chemnitz supuso un duro golpe para las expectativas estratégicas hispanas en la zona ${ }^{104}$. De ahí que fueran precisamente estos dos últimos acontecimientos los que acabaron desengañando a los dirigentes hispanos de qué es lo que se podía esperar de sus aliados germánicos.

La crisis territorial de la Monarquía en 1640, la repentina muerte del Cardenal Infante poco después y las sucesivas derrotas de los ejércitos imperiales frente a los suecos durante esos años y los siguientes, aceleraron una tendencia ya inexorable que ni el cambio de protagonistas (muerte de Fernando II en 1637, de Schönburg en 1640, relevo ese mismo año de Castañeda - primero por Melo, luego por Castel Rodrigo - , caída de Olivares en $1643 . .$. ) pudo detener. Y no se pudo parar porque no era una cuestión coyuntural ni personal sino que estaba enraizada en la propia esencia de las relaciones hispano-imperiales. La idea que fue ganando fuerza con el tiempo y, como hemos visto, insinuada desde casi los mismos inicios del conflicto, no era otra que la necesidad de hacer una paz con Francia por separado o, dicho en otras palabras, romper la unidad de la Casa de Austria y plegarse a una de las principales demandas de Richelieu.

Desde 1642 dicha opinión comenzó a ganar enorme fuerza amparada, en especial, por Baviera y Colonia y acabará por concretarse cuando, una vez puestas en

103. Para los avatares de esta unidad «fantasma», NEGREDO DEL CERRO, F.: «La política centroeuropea de la Monarquía Hispánica (1635-1641). Un contexto para la correspondencia», en ELLIOTT y NEGREDO, Memoriales y Cartas...

104. Este cuerpo de ejército se consideraba imprescindible para que la situación en Flandes no acabara en derrota total. Desde Madrid y Bruselas se presionaba a su general para que lo engrosara al máximo y marchara en campaña lo antes posible para frenar, en especial, los designios de los mariscales franceses, algo que no siempre ocurrió. Para su actuación, ESTEBAN ESTRÍNGANA: «Olivares y el Cardenal Infante en el gobierno de Flandes...», y NEGREDO: «La política centroeuropea...».

Ediciones Universidad de Salamanca / అ@@ Stud. his., H. ${ }^{a}$ mod., 41, n. 1 (2019), pp. 117-152 
marcha las negociaciones de Westfalia, el enviado especial del emperador, el conde de Trauttmansdorff, acuda a las mismas con órdenes claras de alcanzar esta paz, como a la postre ocurrió ${ }^{105}$. Ahora bien, como se ha expuesto, tal resolución no fue fruto de un día ni consecuencia de un acontecimiento bélico determinado, sino el efecto de una incapacidad palmaria de desarrollar políticas comunes por parte de Madrid y Viena que, desde los primeros meses del enfrentamiento con Francia, puede documentarse. En este sentido, el análisis del fracaso de los acuerdos de 1634-1635 ha servido para constatar que, a pesar de los esfuerzos diplomáticos y la retórica confesional y dinástica, el proyecto político conjunto adoleció siempre de enormes carencias que sólo podían camuflarse a partir de una inyección monetaria que acudía en un único sentido. La sensación ya latente en esas fechas de que se subvencionaba sin contraprestaciones, a los pretendidos aliados, no de que se contribuía a su colaboración, se fue acrecentando con los años y cuando la propia crisis de la Monarquía limito su capacidad de crédito, los hechos dieron la razón a quien así pensaba. No es que el dinero fuese el nervio de la guerra - que por supuesto lo era-es que era el único elemento capaz de ganar fidelidades en casi todos los teóricos aliados ${ }^{106}$. Ayunas de un proyecto político conjunto, las dos ramas de la Casa de Austria, fueron incapaces de forjar una alianza plena y efectiva, y entre Nördlingen y Corbie esta frustración quedó de manifiesto.

\section{BIBLIOGRAFÍA}

ABREU Y BERTODANO, J. A. DE.: Colección de los Tratados de Paz de España. Reinado de Felipe IV. Madrid, 1745.

ALDEA VAQUERO, Q.: España y Europa en el siglo XVII. Correspondencia de Saavedra Fajardo. Madrid, CSIC, 4 vols., 1986-2008.

BELADIEZ, E.: España y el Sacro Imperio Romano Germánico. Wallenstein(1583-1634). Madrid, Prensa Española, 1967.

BÉRENGER, J.: «La collaboration militaire austr-espagnole aux XVIe-XVIIe siècles», en MOLINIÉ, A. y MERLE, A. (dirs.): L'Espagne et ses guerres. De la fin de la Reconquête aux guerres d'Indépendance. París, PUF, 2004.

BIRELEY R.: «The Peace of Prague (1635) and the Counterreformation in Germany», The Journal of Modern History, vol. 48, 1, 1976, pp. 31-70.

105. Felipe IV se quejaría amargamente a su confidente sor María de Ágreda de cómo «El Emperador y el Imperio han hecho paz con Francia, harto trabajosa y al parecer poco durable, dejándome a mí fuera y con todos los enemigos a cuestas; pero estoy cierto que le han obligado a hacer esto todos los príncipes del Imperio y sus ministros, pues por su voluntad no lo hiciera nunca el Emperador». Madrid, 8 de diciembre de 1648. SECO SERRANO, C. (ED.): Cartas de sor María de Jesús de Ágreda y de Felipe IV, Madrid, 1958, p. 170.

106. RODRÍGUEZ HERNÁNDEZ: «El precio de la Fidelidad Dinástica...» pp. 174-176.

Ediciones Universidad de Salamanca / @®@@ Stud. his., H. ${ }^{a}$ mod., 41, n. 1 (2019), pp. 117-152 
BOURDEU, E.: Les archevêques de Mayence et la présence espagnole dans le Saint-Empire (XVIe-XVIIe siècle). Madrid, Casa de Velázquez, 2015.

ELLIOTT, J. H.: El Conde-Duque de Olivares. El político en una época de decadencia. Barcelona, Crítica, 1990.

ELLIOTT, J. H., DE LA PEÑA, JOSÉ F. y NEGREDO, F. (eds.): Memoriales y Cartas del Conde Duque de Olivares. Madrid, Marcial Pons-CEEH, 2013.

ELLIOTT, J. H. y NEGREDO DEL CERRO, F. (eds): Memoriales y Cartas del Conde Duque de Olivares, t. II, Politica exterior: Correspondencia entre el Cardenal Infante $y$ don Gaspar de Guzmán. Madrid 2018 [en prensa].

ERNST, H. Madrid und Wien 1632-1637. Politik und Finanzen in den beziebungen zwischen Philipp IV und Ferdinand II. Münster, Aschendorff, 1991.

ESTEBAN ESTRÍNGANA, A.: « «Dar ley a los otros» y emanciparse de ella: balance de hegemonía en las dos guerras de Flandes (1635-1646)», en este mismo dossier.

ESTEBAN ESTRÍNGANA, A.: «Olivares y el Cardenal Infante en el gobierno de Flandes: el desafío franco-holandés a la conservación de la provincias entre 1635-1641», en ELLIOTT, J. H. y NEGREDO DEL CERRO, F. (eds): Memoriales y Cartas del Conde Duque de Olivares, t. II, Politica exterior: Correspondencia entre el Cardenal Infante y don Gaspar de Guzmán. Madrid, 2018 [en prensa].

GIORDANO, S.: «Urbano VIII e la Casa d'Austria durante la Guerra dei Trent'anni. La missione di tre nunzi straordinari nel 1632», en MARTÍNEZ MILLÁN, J. y GONZÁLEZ CUERVA, R. (coords.): La Dinastía de los Austria. Las relaciones entre la Monarquía Católica y el Imperio. Madrid, Polifemo, 2011, 3 vols., pp. 227-247.

GONZÁLEZ CUERVA, R.: Baltasar de Zúniga. Una encrucijada de la Monarquía Hispana (1561-1622). Madrid, Polifemo, 2012.

GÜNTER, H.: Die Habsburger-Liga (1625-1635), Berlín, Ebering, 1908.

ISRAEL, J. I.: «Olivares, el Cardenal Infante y la estrategia de España en los Países Bajos (1635-1643): el camino a Rocroi», en KAGAN, R. L. y PARKER, G. (eds.): España, Europa y el mundo Atlántico. Homenaje a John H. Elliott, Madrid, Marcial Pons, 2001, pp. 347-380.

ISRAEL, J. I.: La República holandesa y el mundo hispánico, 1606-1661, Madrid, Nerea, 1997.

KRAUS, A.: Maximilian I. Bayerns Grosser Kurfürst, Graz, Styria Premium, 1990.

LESAFFER, R.: «Defensive, Warfare, Prevention and Hegemony. The Justifications for the Franco-Spanish War of 1635» (Part I and Part II), Journal of the History of International Law, 8, 2006, pp. 91-123 y 141-179.

MAFFI, D.: «Confesionalismo y razón de estado en la Edad Moderna. El caso de la Valtellina (1637-1639)», Hispania Sacra, 57, 2005, pp. 467-489.

MAFFI, D.: En defensa del Imperio. Los ejércitos de Felipe IV y la guerra por la hegemonía europea (1635-1659). Madrid, Actas, 2014.

MALETTKE, K.: «France's Imperial Policy during the Thirty Years War and the Peace of Westphalia», en BUSSMANN, K. y SCHILLING, H. (eds): 1648: War and Peace in Europe. Münster, 1998, pp. 177-185.

Ediciones Universidad de Salamanca / @®@@ Stud. his., H. ${ }^{a}$ mod., 41, n. 1 (2019), pp. 117-152 
MAREK, P.: «La diplomacia española y la papal en la corte imperial de Fernando II», Studia Historica, 30, 2008, pp. 109-143.

MONOSTORI, T.: «Antineutralidad: An unknown and unpublished book of Diego de Saavedra Fajardo», Janus, 7, 2018, pp. 1-18.

NEGREDO DEL CERRO, F.: «Un episodio español en la Guerra de los Treinta Años: La embajada del marqués de Cadreita al Sacro Imperio y el acercamiento al Elector Sajón (1629-1631)», Hispania, 2015, vol. LXXV, 251, pp. 669-694.

NEGREDO DEL CERRO, F.: La Guerra de los Treinta Años. Una visión desde la Monarquía Hispánica. Madrid, Síntesis, 2016.

NEGREDO DEL CERRO, F.: «¿Una guerra de religión o una religión para la guerra? El elemento confesional en la Guerra de los Treinta Años», Hipogrifo. Revista de literatura y cultura del Siglo de Oro, 7.2, 2019, [en prensa].

NEGREDO DEL CERRO, F.: «La política centroeuropea de la Monarquía Hispánica (1635-1641). Un contexto para la correspondencia.» en ELLIOT'T, J. H. y NEGREDO DEL CERRO, F. (eds): Memoriales y Cartas del Conde Duque de Olivares, t. II, Politica exterior: Correspondencia entre el Cardenal Infante y don Gaspar de Guzmán, Madrid, 2018 [en prensa].

NEGREDO DEL CERRO, F. y VILLALBA PÉREZ, E.: «Los jesuitas y la Monarquía Hispánica en el contexto de la Guerra de los Treinta Años (1625-1635)», Hispania Sacra, LXVII, 136, 2015, pp. 635-672.

PARROTT, D.: «The Causes of the Franco-Spanish War of 1635-59», in BLACK, J. (ed.), The Origins of War in Early Modern Europe. Edimburgo, 1987, pp. 72-111.

PARROTT, D.: Richelieu's Army. War, Government and Society in France, 1624-1642. Cambridge, Cambridge University Press, 2004.

ROBERTS, M.: From Oxenstierna to Charles XII: Four Studies. Cambridge, Cambridge University Press, 2003.

RÓDENAS VILAR, R.: La política europea de España durante la Guerra de Treinta Años (1624-1630). Madrid, CSIC, 1967.

RODRÍGUEZ HERNÁNDEZ, A. J.: «Financial and Military cooperation between the Spanish Crown and the Emperor in the Seventeenth Century», en RAUSCHER, P. (Hg.): Kriegfübrung und Staatsfinanzen. Die Habsburgermonarchie und das Heilige Römische Reich vom Dreissigjährigen Krieg bis zum Ende des habsburgischen Kaisertums 1740, Münster, Aschendorff, 2010, pp. 575-602.

RODRÍGUEZ HERNÁNDEZ, A. J.: «Las limitaciones de la paz: Diplomacia y colaboración económico-militar entre España y el Imperio en torno a la paz de Westfalia (1644-1659)», en MARTÍNEZ MILLÁN, J. y GONZÁLEZ CUERVA, R. (coords.): La Dinastía de los Austria. Las relaciones entre la Monarquía Católica y el Imperio. Madrid, Polifemo, 2011, 3 vols. Vol. II, pp. 1355-1386.

RODRÍGUEZ HERNÁNDEZ, A. J.: «El precio de la Fidelidad Dinástica: Colaboración económica y militar entre la Monarquía Hispánica y el Imperio durante el reinado de Carlos II, 1665-1700» Studia Historica, 33, 2011, pp. 141-176.

SECO SERRANO, C. (Ed.): Cartas de sor María de Jesús de Ágreda y de Felipe IV, Madrid, BAE, 1958.

Ediciones Universidad de Salamanca / @®@@ Stud. his., H. ${ }^{a}$ mod., 41, n. 1 (2019), pp. 117-152 
SKOWRON, R.: «Los aliados de las esperanzas fallidas. La Casa de Austria y los Vasa de Polonia (1598-1648)», en MARTÍNEZ MILLÁN, J. y GONZÁLEZ CUERVA, R. (coords.): La Dinastía de los Austria. Las relaciones entre la Monarquía Católica y el Imperio. Madrid, Polifemo, 2011, 3 vols., vol. II, pp. 997-1021.

STRADLING, R. A.: «Olivares and the origins of the Franco-Spanish War, 1627-1635», English Historical Review, 101, 1986, pp. 68-94.

STRAUB, E.: Pax et Imperium. Spaniens Kampf um seine Friedensordnung in Europa zwischen 1617-1635. Paderborn, Schöningh, 1980.

VERMEIR, R.: En estado de guerra. Felipe IV y Flandes, 1629-1648. Córdoba, Servicio de Publicaciones, 2006.

WEBER, H.: «Richelieu et le Rhin», Revue Historique, 239, 2, 1968, pp. 265-280.

WILSON, P. H.: Europe's Tragedy. A bistory of the Thirty Years War. Londres, Penguin, 2009.

Ediciones Universidad de Salamanca / @@्త $\quad$ Stud. his., H. ${ }^{a}$ mod., 41, n. 1 (2019), pp. 117-152 